\title{
The Role of Evapotranspiration in the Framework of Water Resource Management and Planning Under Shortage Conditions
}

\author{
Giuseppe Mendicino and Alfonso Senatore \\ Department of Soil Conservation, University of Calabria, Arcavacata di Rende (CS)
}

Italy

\section{Introduction}

The increased availability of observed data and of advanced techniques for the analysis of meteo-hydrological information allows an even more detailed description of the evolution of global climate. The results showed by the Fourth Assessment Report (FAR) of the International Panel on Climate Change (IPCC, 2007) about the changes that, starting from 1950, are affecting the atmosphere, the cryosphere and the oceans, confirm global warming. The global average surface temperature has increased in the last 100 years by $0.74^{\circ} \mathrm{C} \pm$ $0.18^{\circ} \mathrm{C}$, accelerating in the last 50 years $\left(0.13^{\circ} \mathrm{C} \pm 0.03^{\circ} \mathrm{C}\right.$ per decade), especially over land (about $0.27^{\circ} \mathrm{C}$ per decade) and at higher northern latitudes. As a consequence, the higher available energy on the surface has speeded up the hydrological cycle. The concentration of the water vapor in the troposphere has increased (1.2 $\pm 0.3 \%$ per decade from 1988 to 2004), while long-period precipitation trends (both positive and negative) in many regions have been observed by analyzing time series from the year 1900 to the year 2005. Changes in temperature and precipitation regimes strongly affect the hydrological cycle. As an example, the increase in temperature has produced a substantial reduction in snow cover in several regions, mainly in spring, and a reduction in the areas covered by seasonal frozen ground (reduction of about $7 \%$ in the northern hemisphere over the latter half of the 20th century). Direct long-term measurements of all the main components of the hydrological cycle are not widely available: in order to assess soil moisture long-term changes, due to the lack of direct measurements the primary approach is to calculate Palmer Drought Severity Index, while long-term stream flow gauge records do not cover entirely and uniformly the world, and they present gaps and different record lengths. However, generally stream flow trends are positively correlated to precipitation, while a common effect of climate change is arising independently on precipitation trends: starting from the '70s a considerable increase of the frequency of extreme hydrological events (floods and droughts) has been observed. Also concerning actual evapotranspiration, direct measurements over global land areas are still very limited, but already the Third Assessment Report (TAR) reported that actual evapotranspiration increased during the second half of the 20th century over most dry regions of the USA and Russia, and, by means of observed precipitation, temperature, 
cloudiness-based surface solar radiation and a land surface model, Qian et al. (2006) found that global land evapotranspiration closely follows variations in land precipitation.

Following the FAR, it is extremely unlikely ( $<5 \%$ probability) that the global warming trend observed in the last half century, whose remarkable characteristics in the history of the Earth seem to be confirmed even by paleo-climatic studies, could be explained without considering external forcings, and is very likely $(>90 \%)$ that the production of greenhouse gases is the main cause of the observed increase in temperature.

Human activities negatively impact on water resource availability, not only contributing to the water cycle changes on a global scale, but also in a more direct way, through the pollution of water courses and aquifers. This pollution is specifically generated by the overexploitation of the soil and chemical contaminants due to agriculture and forestry, by urban waste, transportation and building, and by the over-exploitation of the coastal aquifers, which generates saline water intrusion.

Many of the problems connected to water shortage and to bad water quality are due to not efficient or even inexistent water resources planning and management. Recently, most advanced planning studies have adopted tools for integrated water resources management. Specifically, by now among planners the idea is diffused that a reactive approach, based on the implementation of actions after a drought event has occurred and is perceived, is not adequate and a proactive approach is needed (Yevjevich et al., 1983; Rossi, 2003), based on the development of plans allowing the identification of long- and short-term actions to face drought, and the implementation of such plans, on the basis of timely information provided by a drought monitoring system.

Different measures can be used to cope with water resource crises due to drought. Rossi et al. (2007) show several classifications of these measures: first, the one suggested by Yevjevich et al. (1978) that distinguishes among measures aimed at increasing water supply, reducing demand and minimizing impacts; next, considering the one differentiating reactive and proactive measures (Yevjevich et al., 1983); and finally, the one between long- and short-term measures. The Water Scarcity Drafting Group (2006) disseminated a document specifying a series of mitigation measures that can be adopted in the EU countries. Pereira (2007), starting from a conceptual distinction between water conservation (referred to the measures for the conservation and preservation of water resource) and water saving (referred to the measures aimed at limiting and/or controlling water demand), points out a set of actions that can be adopted in agriculture to reduce the impacts of drought resulting economically, socially and environmentally more competitive than the "classical" proposal of realizing artificial reservoirs, the latter being an alternative preferred in even fewer cases in the countries where water resource planning is more advanced (e.g. Cowie et al., 2002). Finally, the European Commission in the Communication "Addressing the challenge of water scarcity and droughts in the European Union", adopted on July 18, 2007 (COM, 2007), while stating the necessity of progressing towards the full implementation of the Water Framework Directive 2000/60/EC (WFD), underlines the huge potential for water saving across Europe, where people continue to waste at least $20 \%$ of water due to inefficiency, indeed leakages greater than $50 \%$ have been recorded in the irrigation networks. A report connected to the EU Communication (Dworak et al., 2007) estimates a potential water saving in the EU of about $40 \%$. Regarding the strategic paths for future interventions, the enhancement of drought risk management should be achieved also through: developing drought risk management plans; developing an observatory (an European Drought 
Observatory is now available at http://edo.jrc.ec.europa.eu) and an early drought warning system; further optimizing the use of the EU Solidarity Fund and European Mechanism for Civil Protection; fostering water efficient technologies and practices; fostering the emergence of a water-saving culture in Europe.

In this framework, evapotranspiration assessment is of outstanding importance both for planning and monitoring purposes. Its magnitude (mainly referring to potential evapotranspiration) is comparable to the main forcing of the water balance, i.e. precipitation, and for this reason several climatic classifications are based on comparisons between these two quantities, with the aim of determining specific climate conditions for different areas (e.g. Rivas-Martinez, 1995). Furthermore, evapotranspiration is the only component of the water balance with a central role also in the energy and carbon balance, since it directly accounts for hydrological, agricultural and ecological effects of drought events. Specifically, in agriculture evapotranspiration can be closely related to water demand. This means that the role of evapotranspiration, and losses due to evapotranspiration in agriculture (which are foreseeable to a certain extent) can be handled in a way allowing to assure the best conditions for agricultural needs, if water resources management is correctly planned and implemented. Hence, in this chapter evapotranspiration assessment/water demand fulfillment will be considered within the wider framework of water resources management and planning, both for a correct evaluation of the water balance (considering both the hydrological balance and the differences between water requirements and availability), and for determining incoming drought events through appropriate indices (drought monitoring). The issue of reducing water requirements, meaning loss reductions and/or evapotranspiration reductions (mainly in agriculture) will only be touched on, while dealing with methods and tools for water resource management under shortage conditions.

In the next sections, after an analysis of the available water resource and water demand in a southern Italian region (Calabria), the chapter highlights some weaknesses of the regional water system in rainfall deficit conditions, drafting the main strategies of intervention to be adopted to face the different aspects of drought. Then, some guidelines for the proactive management of drought in agriculture are proposed and specifically, by means of a casestudy related to one of the most important agricultural areas in southern Italy (the Sibari Plain), the development of the three most important operational management tools is shown, i.e. the Strategic Plan for long-term interventions, the Management Plan for shortterm interventions and the Contingency Plan for emergency conditions. Drought indices are important tools for correctly drafting these plans: a specific section will provide some insight about them. Finally, some climatologic and hydrologic scenarios over a specific basin are hypothesized, with the aim of assessing water resource availability in the second half of the present century and of verifying whether the intense and prolonged drought periods currently affecting the Calabria region will become ordinary situations in the near future.

\section{Natural water resource}

Since no useful information is available for an estimate of the direct runoff volume on the whole region, natural water resource was determined using a distributed monthly water balance model described by Mendicino \& Versace (2007) and Mendicino et al. (2008a), which extends the approach proposed by Thornthwaite \& Mather (1955) and simulates soil moisture variations, evapotranspiration, and runoff on a $5 \mathrm{~km}$ regular grid (Fig. 1) using data sets that include climatic drivers, vegetation, and soil properties. This model does not 
consider the horizontal motion of water on the land surface, or in the soil (hence no flow routing algorithms are required), and it is based on a simplified mass balance:

$$
\Delta W=P+S M-S A-E T-Q
$$

where $\Delta \mathrm{W}$ is the change in soil moisture storage, $\mathrm{P}$ the precipitation, $\mathrm{SM}$ the snow melt, $\mathrm{SA}$ the snow accumulation, ET the actual evapotranspiration, and $Q$ is the runoff (all the quantities are evaluated in mm month ${ }^{-1}$ ). In the model, potential evapotranspiration PET is estimated through the Priestley-Taylor method (Priestley \& Taylor, 1972), requiring only temperature, air pressure and net radiation data, overcoming the lack of observed wind speed and air humidity data in the analyzed area before the year 2000. In the case of net radiation, monthly values were obtained starting from a modified version of the model originally suggested by Moore et al. (1993). Actual evapotranspiration ET is calculated starting from PET and considering the Accumulated Potential Water Loss (APWL), such as suggested by Thornthwaite \& Mather (1955), which represents the total amount of unsatisfied potential evapotranspiration to which the soil has been subjected.

Because of the significant reforestation campaigns carried out in Calabria after the Second World War, whose results were evident already at the end of 1950s, the starting period for the analysis was assumed to be 1957. The assumption of constant soil use (derived by the Corine Land Cover 2000 project) is justified by the coarse resolution of the model $(5 \mathrm{~km}$ grid). The model schematized in figure 1 was improved also considering: i) that a portion of the rainfall is directly transformed into "instantaneous" runoff (depending on the ratio between actual soil moisture and soil water holding capacity WHC, in its turn derived by combining soil use with a detailed soil texture map of Calabria); ii) an additional very simple snow module, which partitions snow and rain precipitation and regulates snow melt just referring to the current monthly temperature in the cell; iii) that the hydraulic subsoil characteristics are simulated with reservoirs whose rates of depletion vary with the predominating geo-lithological characteristics in the single cells of the model (Mendicino et
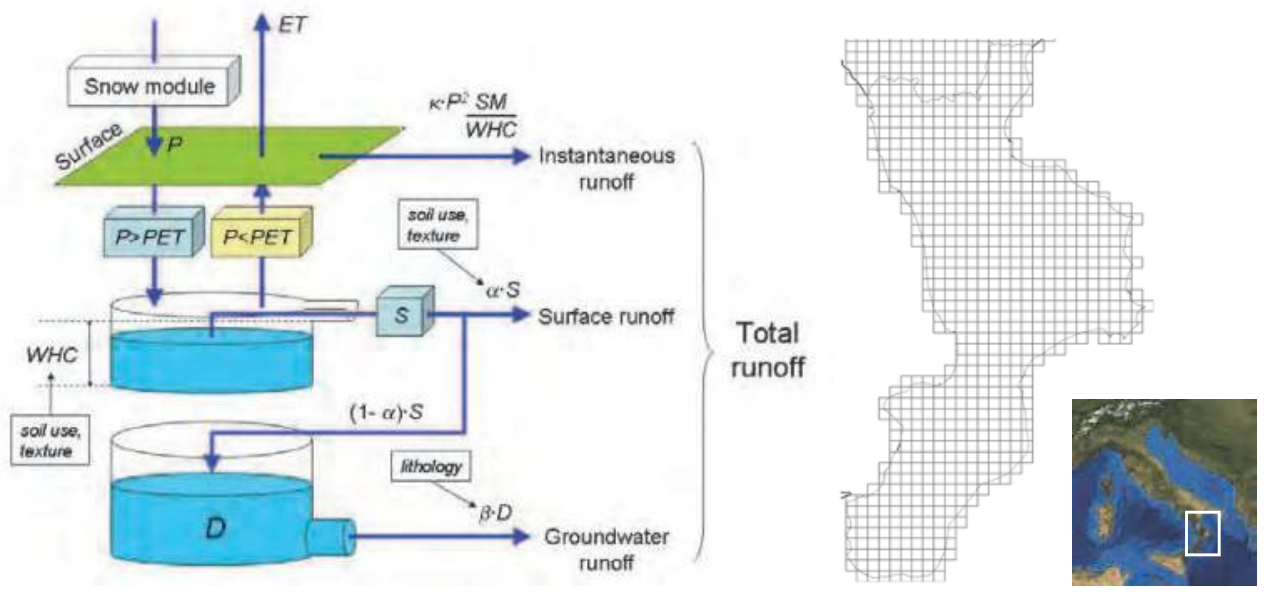

Fig. 1. Schematization of the water balance model and overlay of the $5 \mathrm{~km}$ regular grid in the analyzed region. 
al., 2005). The different characteristics of subsoil leaded to the subdivision of the region into three categories: I) areas with a high capability of producing perennial flow (rocks with high permeability not in the plain); II) areas with mean capability of producing perennial flow (rocks with mean permeability); III) areas with low capability of producing perennial flow (rocks with low permeability or with high permeability in the plain).

The monthly water balance model was validated considering about 2900 monthly runoff values observed in 14 Calabrian catchments during the period 1955-2006 (Fig. 2). Figure 2 also shows the quite satisfactory performance of the model that, besides reproducing the monthly average behaviour of each considered catchment, provided values of the slopes of the regression curves obtained comparing observed and simulated runoff values varying from a minimum of 0.791 (Alli Orso) to a maximum of 1.135 (Esaro La Musica), while the correlation coefficients $r$ varied from 0.447 (Coscile Camerata) to 0.939 (Corace Grascio).
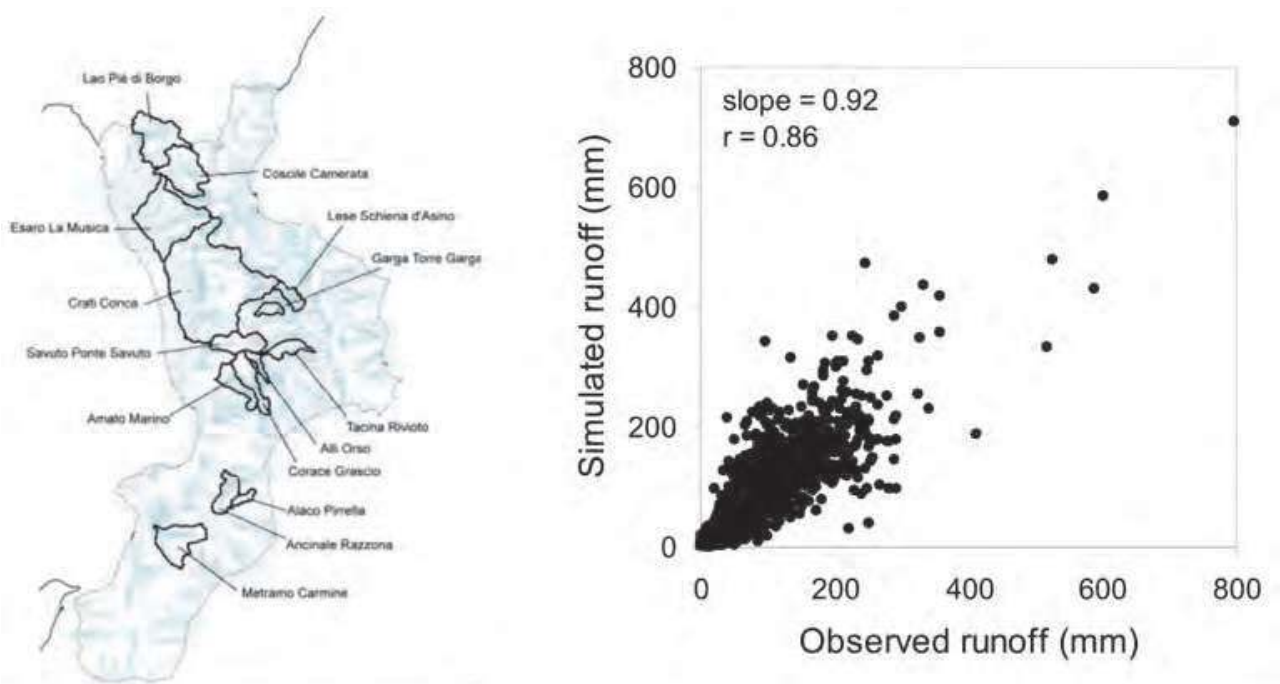

Fig. 2. Spatial distribution of the gauged catchments and comparison between all observed and simulated runoff during the period 1960-2006.

The monthly water balance model was applied on the whole territory of Calabria for the period 1960-2006 on a $5 \mathrm{~km}$ regular grid, where each cell was independent from the others, determining the main components of the hydrological balance in the whole region: precipitation, actual evapotranspiration, soil moisture storage, groundwater volume and instantaneous, surface and subsurface runoff. In several areas of the region a negative trend was observed for many of these variables. Specifically, while the potential evapotranspiration trend was strongly related to increasing temperature, actual evapotranspiration was affected also by changes (reduction) in precipitation. Considering the whole region, the average annual actual evapotranspiration estimated in the analyzed period is $581 \mathrm{~mm}$, equal to about $57.8 \%$ of the average cumulated annual rainfall (potential evapotranspiration is about $110 \%$ ). Figure 3 (left side) shows the average monthly values in the whole region for actual and potential evapotranspiration. The months where a significant difference can be observed are the months from May to September. In these 
months (the less rainy and warmest ones), evaporation of soil moisture accumulated in wintertime exceeds rainfall, requiring irrigation in most of the agricultural areas. Figure 3 (right side) also shows the trend of cumulated annual actual evapotranspiration. The decrease in time of this quantity due to rainfall reduction is partly balanced by the increasing temperatures, hence the negative trend is not significant. It is noteworthy that peaks and troughs are generally dependent on rainy (e.g. 2005) or not rainy (e.g. 2001) years, even though rainfall distribution during the single year also affects the evapotranspirative phenomenon. The correlation coefficient between cumulated annual actual evapotranspiration and precipitation in the period 1960-2006 was 0.638.
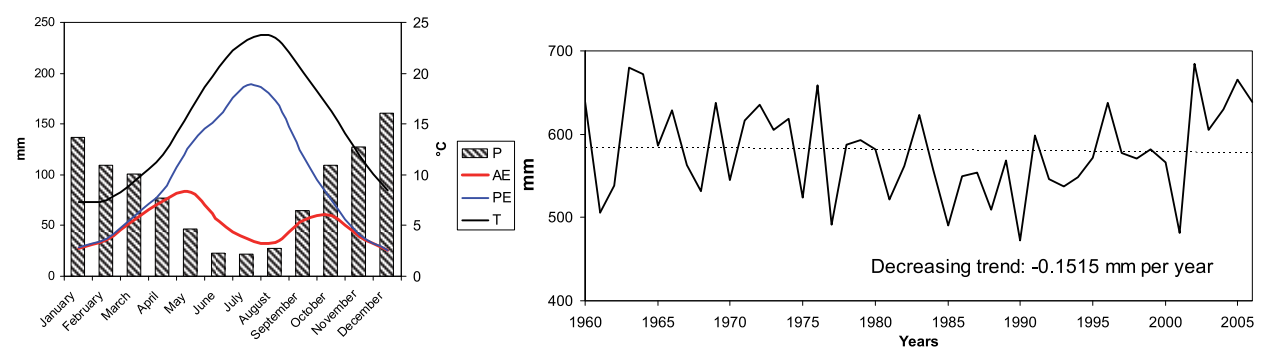

Fig. 3. Left: average monthly values in Calabria of actual (AE) and potential evapotranspiration (PE), precipitation (P) and temperature (T) during the period 1960-2006. Right: trend of cumulated annual actual evapotranspiration.

\section{Water demand and availability}

The water balance between available water resource and water demand is the starting point for a correct water management. One of the main problems occurring in this phase is the general lack of observed data, obliging to synthetic estimates of water availability and several levels of approximation in the assessment of water needs, mainly for irrigation and for determining the management rules of the reservoirs.

In this context, the water balance on the Calabrian region was carried out considering also withdrawals from springs, streams, reservoirs and wells for irrigation and for potable uses, adopting two sequential simulation models. The former is a modified version of the distributed hydrological model, where the natural water balance is integrated with the withdrawal for irrigation and potable uses, producing (output variable) a residual availability. This water availability is used in a second GIS-based model considering the effects of diversions and reservoirs.

In the first model, inside a single $5 \mathrm{~km}$ squared cell can co-exist both wells and springs used to feed small irrigation systems or few users, located in the same cell, and wells and springs used for water mains collecting water outside the cell. If both the points where the water is withdrawn and used are inside the same cell (this happens only for wells for irrigation purposes), the schematization shown in figure 4a is adopted, hypothesizing that inside the cell a known volume is transferred monthly from the subsoil reservoir to the surface as an "added" precipitation (owing to the irrigation). This volume has to be summed to the meteorological precipitation and is subjected to the cycle simulated by the water balance, increasing the soil moisture and actual evapotranspiration and eventually feeding the 
aquifer from which it has been withdrawn. Instead, if the cell where the water is withdrawn does not coincide with the cell where it is used (that is only the case of regional water mains) then the schematization shown in figure $4 \mathrm{~b}$ is adopted. The source cell is subjected to a reduction of the volume of the subsoil reservoir, while the water is hypothesized to reach directly the water stream in the destination cell, feeding the surface runoff with a restitution coefficient equal to 0.7 .

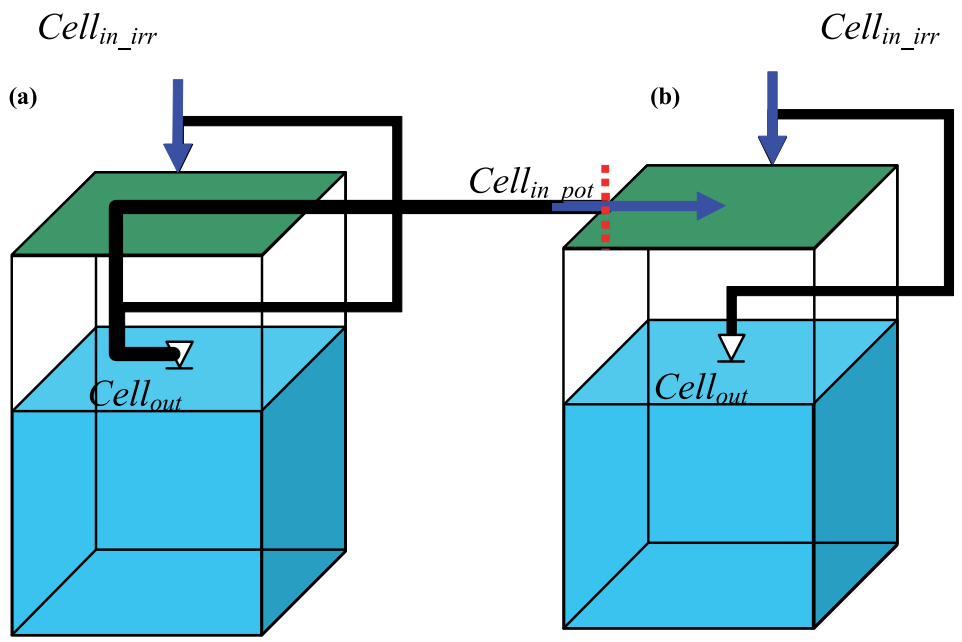

Fig. 4. Schematization of the modified water balance model considering withdrawals for irrigation and potable uses.

Summarizing, the proposed model allows that every month for each cell a volume cell $_{\text {out }}$ can be extracted from the subsoil reservoir, which is equal to the withdrawals for irrigation and potable purposes, that a volume cell in_irr $_{\text {c }}$ can be added like a supplementary precipitation representing the water derived from the same cell and used for irrigation, and finally, that a volume cell $_{\text {in_pot }}$ can be added like a supplementary surface runoff accounting for the water come in the cell to satisfy the potable uses. All the data related to potable and irrigation withdrawals were derived from several official sources, even if sometimes incomplete, and were aggregated at the resolution of the water balance model. Figure 5 shows the distribution of the regional water mains and of the local water distribution systems.

The modified natural water balance is the input of the commercial GIS-based model Mike Basin (DHI Software), accounting for the effects of diversions and reservoirs aimed at satisfying irrigation, hydro-power, civil and industrial requirements (Fig. 6). The lack of actual information about the management rules of reservoirs led to hypothesize several working schemes for the definition of the optimal water balance. Finally, for all the analyzed reservoirs the minimum flow requirements were considered following two different approaches: the former proposed by the Regional Basin Authority (very conservative, especially for some typical Calabrian rivers, called fiumare, characterized by no flow conditions for a relevant part of the year) and; the latter based on the $Q_{7,10}$ flow, i.e. the lowest 7 consecutive-day average flow characterized by a 10 years time period.

In the case of the irrigation demand (i.e. water requirements for balancing evapotranspiration losses), a detailed analysis was carried out on each irrigation district 
(Fig. 7) during the irrigation season April - September. Specifically, the assessment of the effective water consumption was determined by considering different seasonal (spring, summer, autumn) soil use spatial distributions (e.g. in Table 1). For each soil use the seasonal irrigation demand $\left(\mathrm{m}^{3} / \mathrm{ha}\right.$ ) of the crops (Table 2$)$ was achieved. The same was split monthly taking into account that the highest request is obtained during the trimester June August (Table 3). An adequately detailed knowledge of the irrigation network allowed the correct estimate of the possible uptake of volumes to/from other cells. It is noteworthy to highlight that all the information related to soil use and water requirements were aggregated at the resolution of the model, i.e. $5 \times 5 \mathrm{~km}^{2}$, for the whole region.

In the proposed analysis the quite small volumes related to industrial areas were neglected.
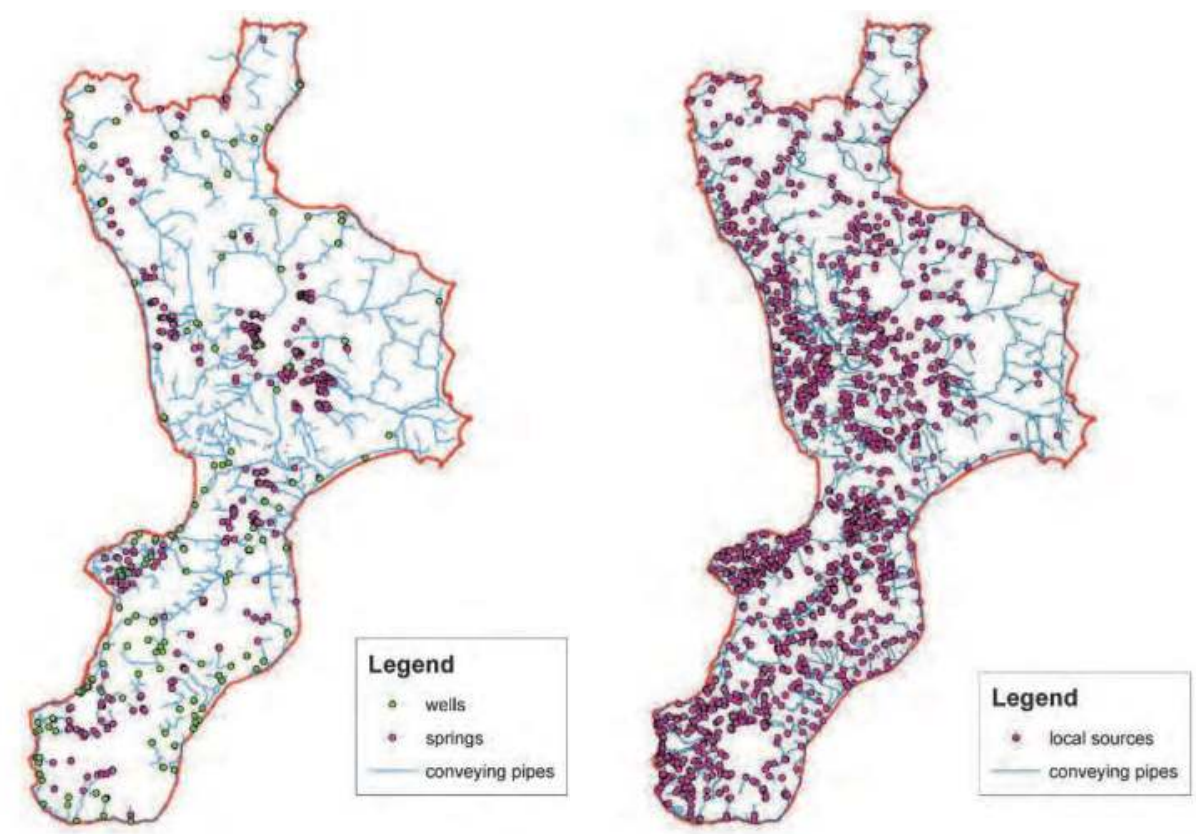

Fig. 5. Left: regional water mains (479 springs, 281 wells and about 2000 conveying pipes). Right: local water distribution systems (over 1200 springs and wells).

Water balance results showed that, for average conditions, the residual annual water availability is great, even if some weaknesses arise. Among these, the strong differences in the seasonal precipitation, which is mainly concentrated in the wet winter period $(80-90 \%)$, require an accurate management of the volumes stored in natural and artificial reservoirs for facing the hot and dry Mediterranean summer. Furthermore, the decrepitude of several conveying pipes has to be considered with remarkable water losses, and the negative precipitation trend due to climate change that seems to be relevant in Calabria (a preliminary analysis about future climate scenarios in Calabria is shown in the $6^{\text {th }}$ section). The weaknesses pointed out in normal conditions suggested water resources availability should be analyzed when drought conditions occur. Specifically, through the use of the Standardized Precipitation Index (SPI, McKee et al., 1993) intensity and duration of droughts were determined on the whole Calabrian region. 


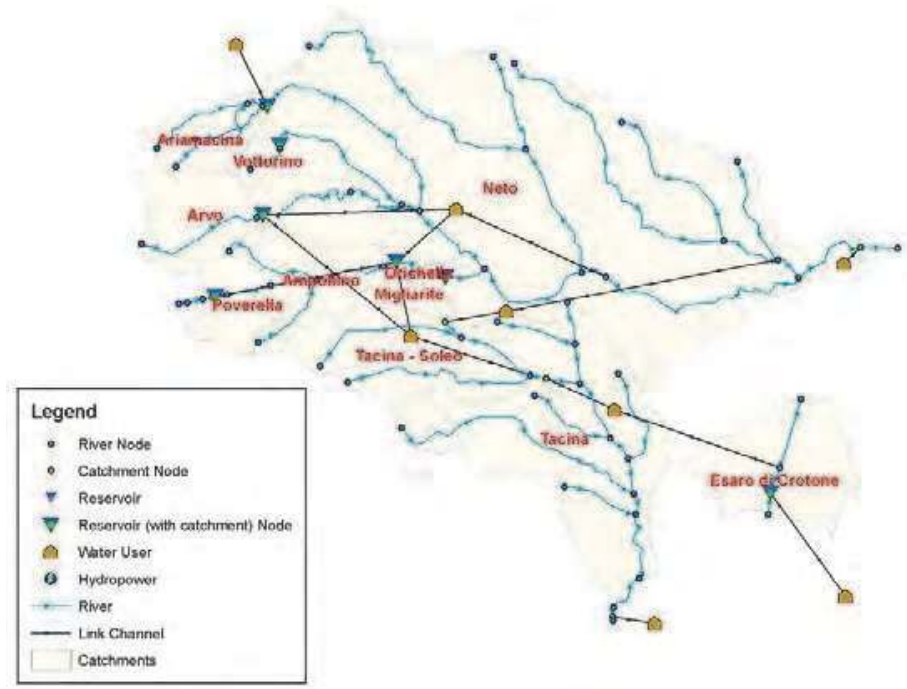

Fig. 6. Example of water system schematization realized within the GIS-based model Mike Basin.

\begin{tabular}{|c|l|c|c|c|}
\hline \multicolumn{1}{|c|}{ Crops } & Spring & \multicolumn{1}{c|}{ Summer } & Autumn \\
\hline Code & \multicolumn{1}{|c|}{ Description } & \multicolumn{2}{c|}{ Soil use (ha) } \\
\hline 2121 & Spring-summer herbaceous crops & & 14.115 & \\
\hline 2122 & $\begin{array}{l}\text { Summer-autumn/spring } \\
\text { horticultural crops }\end{array}$ & & & 14.115 \\
\hline 2123 & $\begin{array}{l}\text { Spring-summer horticultural } \\
\text { crops }\end{array}$ & & & \\
\hline 2211 & Irrigated vineyards & 4.536 & 4.536 & 4.536 \\
\hline 2221 & Irrigated orchards & 328.791 & 328.791 & 328.791 \\
\hline 2231 & Irrigated olive groves & 95.788 & 95.788 & 95.788 \\
\hline
\end{tabular}

Table 1. Seasonal soil use for a generic irrigation district.

For each of the most significant Calabrian basins, and for each month of the period 19602006, a mean SPI areal value was calculated for different time scales (1-, 3-, 6-, 12-, 24- and 48-months), with the aim of highlighting the longest and most intense drought periods (Fig. 8). Drought indices are essential at all levels of the planning process. The reader is referred to section 5 for a brief review of the most diffused ones.

Usually, the beginning of a drought period can be defined when SPI values are lower than -1.0, and its end when the values come back positive. Nevertheless, based on a historical analysis of the official declarations of "natural disaster" in Calabria due to drought, even a 12-month SPI value equal to -0.7 was observed to be adequate as a drought threshold. Hence, when a generic month presented a 12-month SPI value lower than -0.7, it was considered a drought month, and the correspondent total runoff simulated with the water balance model was taken into account. The aggregation, from January to December, of the average runoff estimated during the drought months leaded to the definition of a so-called "scarce year" whose runoff values, 
even if statistically less probable than the ones of the single months, pointed out the possibility of extremely critical situations in Calabria, with a reduction of total runoff up to $43 \%$. This analysis introduces issues related both to the management of water shortage and to the mitigation of drought through the use of restrictive measures. The development and implementation of strategic and emergency plans are primary tools to face the different aspects of drought phenomenon, as it is shown in the next paragraph.

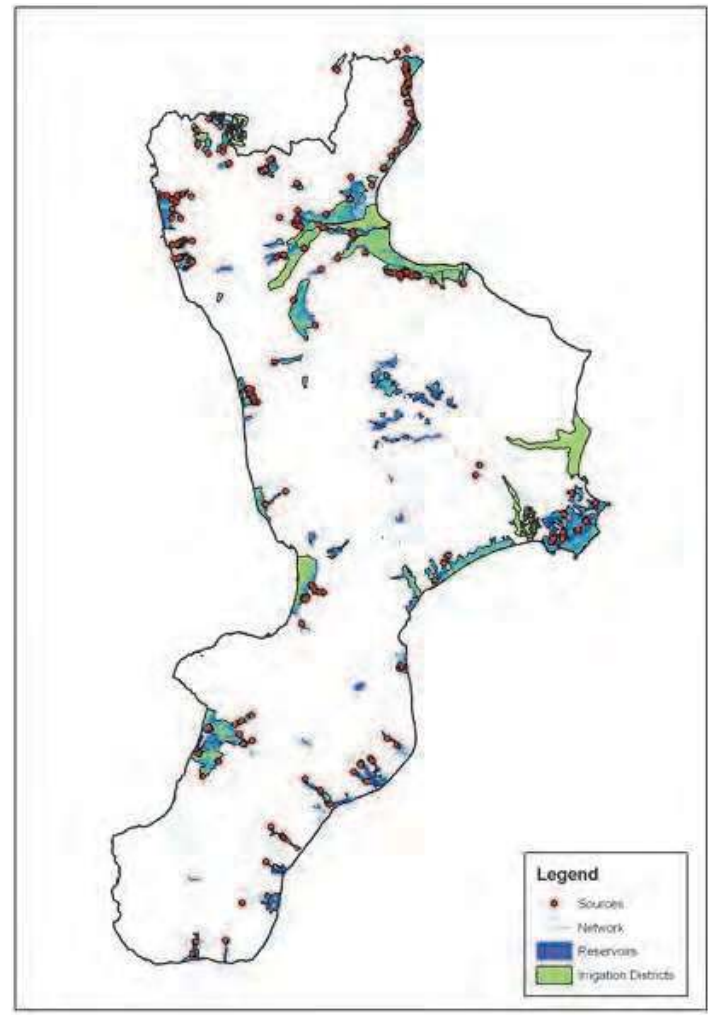

Fig. 7. Calabrian irrigation districts and network systems.

\begin{tabular}{|c|l|c|}
\hline Code & \multicolumn{1}{|c|}{ Description } & Irrigation demand $\left(\mathrm{m}^{3} / \mathrm{ha}\right)$ \\
\hline 2121 & Spring-summer herbaceous crops & 7000 \\
\hline 2122 & Summer-autumn/spring horticultural crops & 7600 \\
\hline 2123 & Spring-summer horticultural crops & 5000 \\
\hline 2125 & Greenhouse crops & 9000 \\
\hline 213 & Rice fields & 15000 \\
\hline 2211 & Irrigated vineyards & 3500 \\
\hline 2221 & Irrigated orchards & 5000 \\
\hline 2231 & Irrigated olive groves & 3000 \\
\hline
\end{tabular}

Table 2. Seasonal irrigation demand $\left(\mathrm{m}^{3} / \mathrm{ha}\right)$ of the crops. 
The Role of Evapotranspiration in the Framework of

Water Resource Management and Planning Under Shortage Conditions

\begin{tabular}{|c|l|c|c|c|c|c|c|c|}
\hline Code & \multicolumn{1}{|c|}{ Description } & $\mathrm{A}$ & $\mathrm{M}$ & $\mathrm{J}$ & $\mathrm{J}$ & $\mathrm{A}$ & $\mathrm{S}$ & TOT \\
\hline 2121 & $\begin{array}{l}\text { Spring-summer } \\
\text { herbaceous crops }\end{array}$ & 0 & 858 & 1497 & 2337 & 1445 & 863 & 7000 \\
\hline 2122 & $\begin{array}{l}\text { Summer-autumn/spring } \\
\text { horticultural crops }\end{array}$ & 163 & 745 & 1719 & 2450 & 1663 & 861 & 7600 \\
\hline 2123 & $\begin{array}{l}\text { Spring-summer } \\
\text { horticultural crops }\end{array}$ & 164 & 751 & 1733 & 2352 & 0 & 0 & 5000 \\
\hline 2125 & Greenhouse crops & 193 & 882 & 2035 & 2901 & 1969 & 1020 & 9000 \\
\hline 213 & Rice fields & 3780 & 3240 & 3240 & 3240 & 1500 & 0 & 15000 \\
\hline 2211 & Irrigated vineyards & 0 & 0 & 1063 & 1411 & 1026 & 0 & 3500 \\
\hline 2221 & Irrigated orchards & 0 & 0 & 1349 & 2125 & 1168 & 458 & 5000 \\
\hline 2231 & Irrigated olive groves & 0 & 0 & 894 & 1249 & 857 & 0 & 3000 \\
\hline
\end{tabular}

Table 3. Monthly irrigation demand $\left(\mathrm{m}^{3} / \mathrm{ha}\right)$ of the crops.

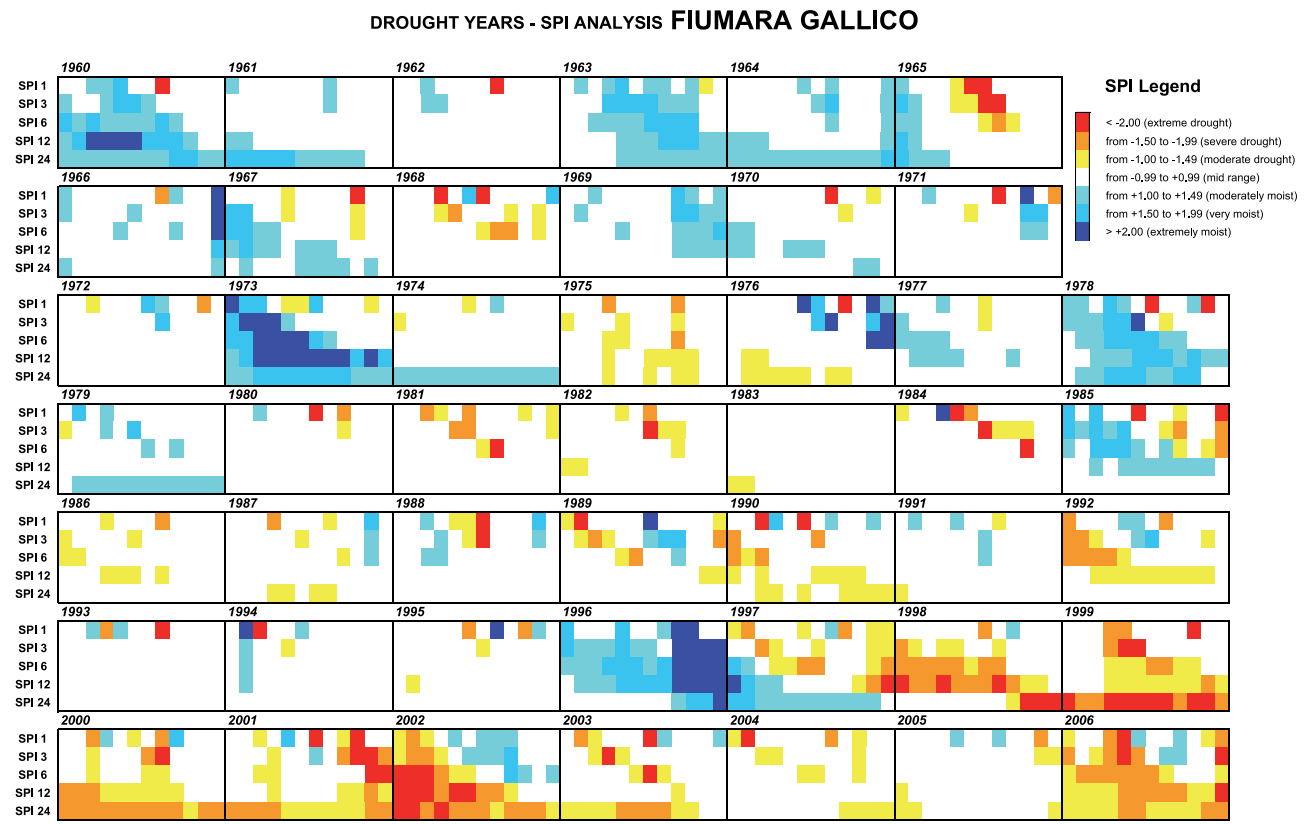

Fig. 8. Temporal evolution of SPI values in a generic Calabrian river basin. Red squares correspond to drier periods.

\section{Water resource management under shortage conditions}

In its 2007 Communication (COM, 2007) the European Commission stated that the challenge of water scarcity and droughts needs to be addressed both as an essential environmental issue and as a precondition for sustainable economic growth in Europe, and highlighted the necessity of progressing towards full implementation of the EU Water Framework Directive (WFD) 2000/60. The WFD is the EU's flagship Directive on water policy, explicitly defining 
long-term planning as the main tool for ensuring good status of water resources. Nevertheless, it does not indicate criteria and actions to face risk of drought, delegating National Legislations to concretely realize its framework (after a series of yearly follow-up reports, a policy review is foreseen for 2012 at the EU level).

In Italy the EU WFD was taken into account with the Legislative Decree 152/2006 on environmental protection. Though this act is quite recent, it seems to be far from being adequate to actually cope with drought, mainly because it does not stress the necessity of passing from a reactive to a proactive approach, based on preparedness and mitigation actions planned in advance with the contribution of all the involved stakeholders, ready to be implemented when drought phenomena occur.

Within a comprehensive drought management planning process, Rossi et al. (2007) proposed the identification of three main tools: Strategic Water Shortage Preparedness Plan, Water Supply System Management Plan and Drought Contingency Plan. Following, an example of application of the proposed guidelines is shown for the planning of the best mix of measures needed for coping with drought phenomena on one of the most important agricultural areas in southern Italy, the Low Esaro and Sibari Plain (Mendicino et al., 2008b). It is noteworthy that in the proposed example (water shortage planning in the agricultural sector) water demand is strictly correlated to the amount of water needed from crops for facing lack of precipitation and high potential evapotranspiration during summer (see Table 3 ). Hence, in this case the planning process is triggered by the need of coping with the high water loss due to evapotranspiration in a particularly dry period of the year. As it is explained in the next sections, this objective can be reached by means of demand reduction, water supply increase or impacts minimization measures, and considering long-, mediumand short-term actions.

\subsection{Methods and tools}

The Agricultural Strategic Water Shortage Preparedness Plan (ASP) is aimed at obtaining the reduction of drought vulnerability in the analyzed area through the implementation in normal conditions of long term mitigation measures, consisting in a series of structural and non-structural actions applied in the water supply system. Usually, structural measures are economically expensive and require the use of many human resources. However, their effects are easier to be foreseen than the effects produced by the nonstructural mitigation actions, in their turn usually more accepted by all the stakeholders. The long term mitigation measures are specifically indicated in the systems characterized by a low level of reliability and are oriented at improving the water balance in the analyzed system. These actions not only enhance the reliability of the system through fulfilling water requirements, but also reduce its vulnerability with respect to future drought events, fulfilling three main objectives: i) water demand reduction; ii) water supply increase and improvement of the efficiency of the system; iii) minimization of the impacts. Within the actions reducing water demand, some are directly aimed at reducing evapotranspiration by adopting appropriate agronomic techniques, such as e.g. irrigating during non windy periods for minimizing wind drift losses, or early defoliation to reduce crop transpiration surface (for a deeper description, the reader is referred to Pereira, 2007). In table 4 the long term measures that can be potentially adopted in agriculture are listed, subdivided considering their main objectives. 


\begin{tabular}{|c|c|}
\hline Category & Long-term actions \\
\hline \multirow{4}{*}{$\begin{array}{c}\text { Demand } \\
\text { reduction }\end{array}$} & Economic incentives for water saving and sanctions for wastes \\
\cline { 2 - 3 } & Agronomic techniques and irrigation systems for reducing water \\
consumption (e.g. Pereira, 2007)
\end{tabular}

Table 4. Main long term drought mitigation measures in agriculture (adapted from Rossi et al., 2007, and Georgia Dept. Of Natural Resources, 2003).

Since the ASP has to be drawn up choosing among several combinations of long-term mitigation measures, a suitable evaluation procedure has to be adopted. A multi-criteria technique could provide an as objective as possible comparison among different alternatives, according to a series of economic, environmental and social criteria, and taking into account the point of view of all the stakeholders. The tool adopted in this study for multi-criteria analysis is the software NAIADE (Munda, 1995).

The ASP should be prepared by the Basin or Hydrographic District Authorities, which are the bodies responsible for planning, and corresponds to the Drought Management Plan included into the River Basin Management Plan provided in the WFD.

Once the long-term mitigation measures are defined, an Agricultural Water Supply System Management Plan (AMP) has to be developed with the aim of: defining the best mix of long and short-term measures to avoid the beginning of a real water emergency; estimating the costs and the financing sources for the chosen mitigation measures, and; fostering the stakeholder participation and exchanges. It is prepared by the authority responsible for agricultural water management (i.e. the Land Reclamation Consortium), and the operative measures defined have to be adopted according to the values of early warning indicators, showing Normal, Pre-Alert or Alert conditions. The threshold values of the indicators can be chosen through an objective function or, if several aspects have to be accounted for, through a multi-criteria analysis. 
In table 5 the short term measures that can be potentially adopted in agriculture are shown, subdivided on the basis of their principal objectives. With respect to the long-term mitigation measures, in this case the actions in the "demand reduction" category implicitly accept a certain percentage of water stress for the crops, because they are only aimed to reduce water consumption, without taking into account crop conditions. On the contrary, former long-term mitigation measures suggested some structural actions (i.e. actions to be adopted always) aimed at limiting some additional evapotranspiration due, e.g., to not correct irrigation practices, and that could be avoided without consequences for the crop. In brief, adopting the AMP evapotranspiration losses could be not completely compensated, and the farmers should be supported in assessing how to minimize water stress effects adopting even more specific agronomic techniques.

\begin{tabular}{|c|c|}
\hline Category & Short-term actions \\
\hline \multirow{4}{*}{ Demand reduction } & Public information campaign for water saving \\
\hline & Restriction of irrigation of annual crops \\
\hline & Pricing (discourage excessive water use) \\
\hline & Mandatory rationing \\
\hline \multirow{4}{*}{ Water supply increase } & $\begin{array}{l}\text { Improvement of existing water systems efficiency (leak } \\
\text { detection programs, new operating rules, etc.) }\end{array}$ \\
\hline & $\begin{array}{c}\text { Use of emergency sources (additional sources of low quality } \\
\text { and/or high exploitation cost) }\end{array}$ \\
\hline & Over exploitation of aquifers (use of strategic reserves) \\
\hline & $\begin{array}{c}\text { Increased diversion by relaxing ecological or recreational use } \\
\text { constraints }\end{array}$ \\
\hline \multirow{4}{*}{ Impacts minimization } & Temporary reallocation of water resources \\
\hline & Public aids to compensate income losses \\
\hline & Tax reduction or delay of payment deadline \\
\hline & Public aids for crops insurance \\
\hline
\end{tabular}

Table 5. Main short term mitigation measures in agriculture (adapted from Rossi et al., 2007).

If a particularly severe drought occurs, and the indicators signal Alarm conditions, the Agricultural Drought Contingency Plan (ACP) has to be adopted, defining the most appropriate short-term measures to reduce the impact of emergency situations. In this case the efforts are turned to protect the essential activities of the agricultural system, and the threshold values of the indicators have to be chosen taking into account this objective, preferably using a probabilistic approach, that allows the decision-makers to evaluate the effective risk of having water deficit for different scenarios. The ACP should be prepared by the Basin or Hydrographic District Authorities, with the collaboration of the Civil Protection.

Such as in the AMP, also in the ACP the assessment of crop losses can be made through production functions. In the case of extreme and particularly prolonged drought also the damage to perennial crops, the excessive decrease of the water tables of the aquifers, sea water intrusion, ecological damages to aquatic flora and fauna have to be considered. Some of this damage can be irreversible and can also influence crop production in the following years. 


\subsection{Case study}

The core of the analyzed water supply system is the Farneto Dam (Fig. 9), closing the Esaro Catchment (about $245.4 \mathrm{~km}^{2}$ ) in southern Italy. The dam is aimed at: (i) containing the ordinary floods and mitigating the extraordinary ones, according to the condition that the reservoir level is maintained almost empty from October to March; (ii) supplying water (about $30 \mathrm{hm}^{3}$ from April to September) to the downstream agricultural area (about $85 \mathrm{~km}^{2}$ ), sited in the Low Esaro and Sibari Plain. At present about $63 \%$ of the irrigable area is based on open channel irrigation systems.

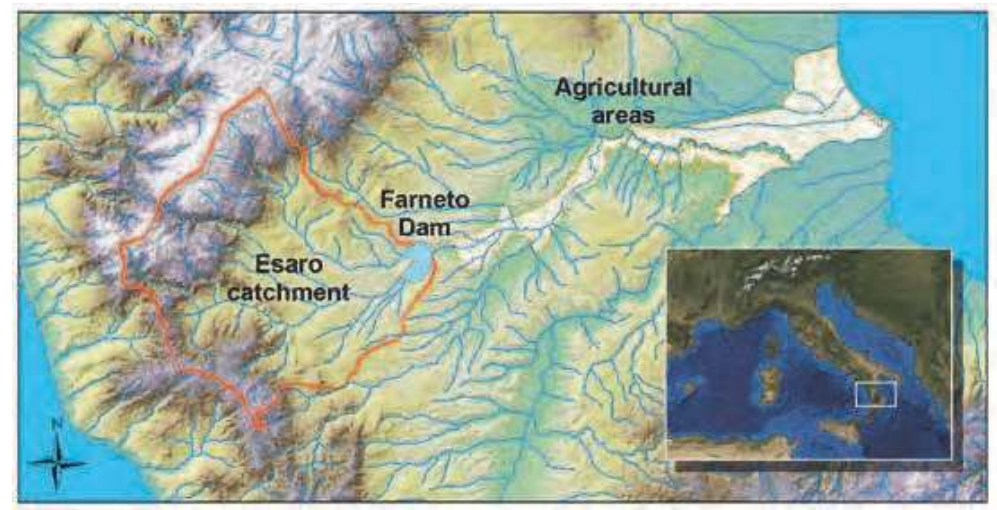

Fig. 9. Study area for the development of the planning process.

\subsection{Applying the Agricultural Strategic Plan}

Table 6 shows 13 selected alternatives (from A to M), obtained combining the following six long-term mitigation measures: 0) System in current configuration; 1) Modernization of the irrigation network for reducing water losses and evaporation (it has been calculated that the efficiency of the actual scenario is equal to $67 \%$, while the efficiency of the "modernized" scenario will be $80 \%$; Mendicino et al., 2008b); 2) Construction of farm ponds; 3) Construction of a new upstream dam; 4) Economic incentives and educational activities for water saving; 5) Allowing the dam to store a little volume during the winter (i.e. dam not empty in March).

\begin{tabular}{|c|c|c|c|c|c|c|c|c|c|c|c|c|c|}
\hline & \multicolumn{10}{|c|}{ Alternatives } \\
\hline Measure & $\mathrm{A}$ & $\mathrm{B}$ & $\mathrm{C}$ & $\mathrm{D}$ & $\mathrm{E}$ & $\mathrm{F}$ & $\mathrm{G}$ & $\mathrm{H}$ & $\mathrm{I}$ & $\mathrm{J}$ & $\mathrm{K}$ & $\mathrm{L}$ & $\mathrm{M}$ \\
\hline 0 & $\mathrm{X}$ & & & & & & & & & & & & \\
\hline 1 & & $\mathrm{X}$ & & & & $\mathrm{X}$ & $\mathrm{X}$ & & & $\mathrm{X}$ & & & $\mathrm{X}$ \\
\hline 2 & & & $\mathrm{X}$ & & & & & & & & $\mathrm{X}$ & & \\
\hline 3 & & & & & & & & $\mathrm{X}$ & & & & $\mathrm{X}$ & $\mathrm{X}$ \\
\hline 4 & & & & $\mathrm{X}$ & & $\mathrm{X}$ & & & $\mathrm{X}$ & $\mathrm{X}$ & $\mathrm{X}$ & $\mathrm{X}$ & $\mathrm{X}$ \\
\hline 5 & & & & & $\mathrm{X}$ & & $\mathrm{X}$ & $\mathrm{X}$ & $\mathrm{X}$ & $\mathrm{X}$ & $\mathrm{X}$ & $\mathrm{X}$ & $\mathrm{X}$ \\
\hline
\end{tabular}

Table 6. Long-term mitigation measures and alternatives.

The alternatives were compared within the DSS tool NAIADE according to 4 economic criteria (construction costs of infrastructures, operation and maintenance costs, crop yield 
losses and amount of public aids needed), 2 environmental criteria (failures to meet ecological requirements and reversibility of the alternatives) and 4 social criteria (system vulnerability, temporal reliability, realization time of the infrastructures and employment increase). Since the observed period is short in order to evaluate the criteria and is characterized by few drought events, two monthly synthetic temperature and precipitation series of 1000 years were generated as input of the water balance model providing the corresponding runoff values.

Within the analysis carried out with NAIADE the final ranking of the alternatives comes from the intersection of two separate rankings. The former $\Phi^{+}$is based on the "better" and "much better" preference relations, hence it points out how an alternative is "better" than the others. The latter $\Phi$ - is based on the "worse" and "much worse" preference relations, and indicates how an alternative is "worse" than the others.

The two rankings are different, since one alternative could result slightly better than the others with respect to few criteria and at the same time could result worse with respect to many criteria, or vice versa. In figure 10 the partial rankings and the final ranking are shown. The most efficient alternative is the "J", where measures 1,4 and 5 are considered together. The alternative " $\mathrm{M}^{\text {", }}$ mainly characterized by the construction of a new upstream dam, is the best only in the $\Phi^{+}$ranking. A sensitivity analysis, carried out to assess the robustness of the achieved solution, showed a substantial stability of the ranking, constantly confirming alternative $\mathrm{J}$ as the optimal one. It is pointed out that alternative $\mathrm{J}$ is made up also by measure 1), allowing a reduction of evaporation losses.

$\Phi+$ Ranking

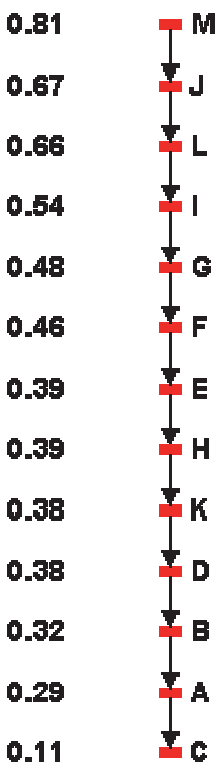

Ф- Ranking

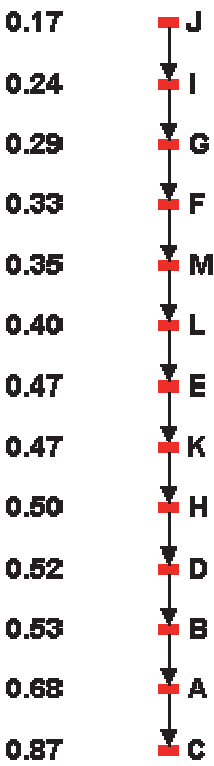

Final ranking

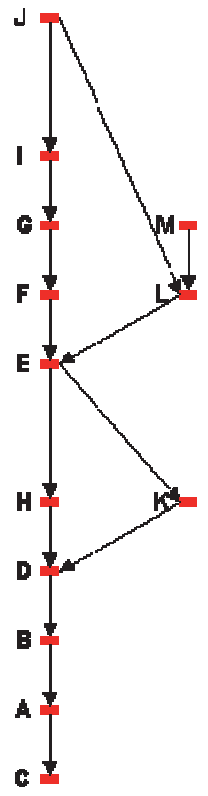

Fig. 10. Partial and final ranking of the drought mitigation alternatives in the Esaro River Basin. 


\subsection{Applying the Agricultural Management Plan}

The AMP is aimed at defining the indicators and the triggers for establishing the Normal, Pre-Alert and Alert conditions for the agricultural areas of the system. It has to take into account the guidelines provided by the ASP. In fact, it has to select the best combination among the optimal long-term mitigation measure previously determined (J) and the several short-term measures that can be adopted to manage water deficits on the analyzed area. Whereas the long-term measure $\mathrm{J}$ is adopted continuously, the short-term measures vary following the status of the system. Specifically, for this case study:

- in Normal condition no short-term actions are taken;

- when Pre-Alert condition occurs, then exploitation of the groundwater resources in the irrigated area till 1/3 of maximum estimated volume is considered;

- when Alert condition occurs, then exploitation of the groundwater resources like in the Pre-Alert condition, the reduction of the release for minimum instream flow till $50 \%$ and the reduction of the release for irrigation (till $80 \%$ of the requirements) are taken into account. When alert condition occurs, the farmer is aware that the evapotranspiration losses cannot be completely compensated.

With the aim of determining the threshold values of the indices indicating the passage from one status to another, for every month from April to September a multicriteria analysis of the effects through NAIADE was carried out. The conflicting objectives to minimize are:

- the vulnerability of the system (including the assessment of crop losses due to reduced irrigation, made through specific production functions);

- groundwater withdrawals;

- $\quad$ the failures to meet the minimum instream flow.

For each month, starting from April, an impact matrix was achieved where, on the basis of the criteria selected for the fulfillment of the objectives, the optimal combination of the thresholds triggering the Pre-Alert and Alert status was selected (Fig. 11). The selected index for the definition of the drought thresholds is the volume stored in the dam from May to
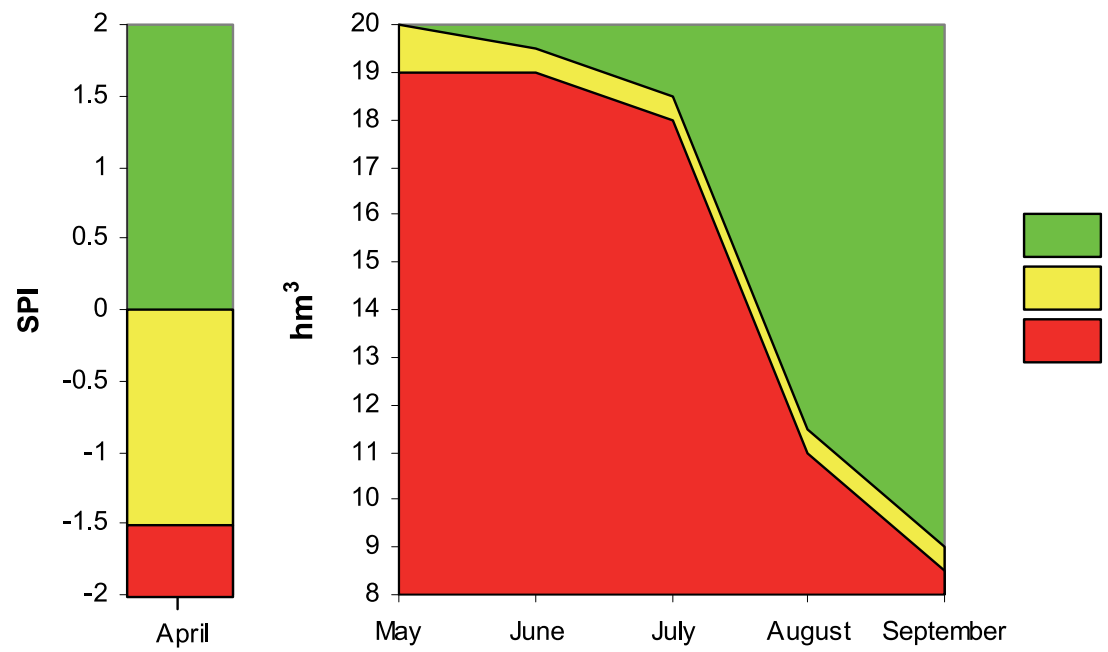

Normal

Pre-Alert

Alert

Fig. 11. Pre-Alert and Alert thresholds defined in the AMP. 
September, while for the month of April a meteorological index was chosen, since owing to the rules adopted for dam management, at the end of March the dam level is not a significant index. For the month of April an analysis was carried out relating the yearly irrigation deficit to the 6 month-SPI calculated in March (considering in this way the first six months of the hydrologic year, from October to March). In the selection of the threshold values a rule was followed considering that, if the multicriteria analysis provides more optimal solutions, the one with the lowest irrigation deficit is selected.

\subsection{Applying the Agricultural Contingency Plan}

The first objective of the ACP is the definition of indices and their thresholds for univocally establishing the beginning of an emergency situation. Since the hydrologic analysis in April shows that the water demand is always less than the water availability in the Farneto del Principe Dam, and that every year the volume stored increases during this month, the thresholds are selected starting from May, choosing as an index, such as in the AMP, the volume stored in the dam. Furthermore, since using the 1000-year series of generated meteorological data the application of the two previous Plans determined a very high temporal reliability of the system $(98.7 \%)$, it is not useful to evaluate the emergency thresholds considering the few residual years. Hence, the adopted approach was based on a probabilistic analysis of the system failures and deficit percentage of the demand.

Specifically, hypothesizing that all the short-term measures were already adopted, the 1000year series of generated meteorological data, for every month and for different fixed initial volumes stored, were used to assess the probability of having failures in fulfilling demand either in the same month or in the subsequent irrigation period, and the deficit percentage with respect to demand. The results, allowing the decision-makers to evaluate the effective risk of having water deficit for a specific storage in a specific month, are shown (from May to August) in figure 12.
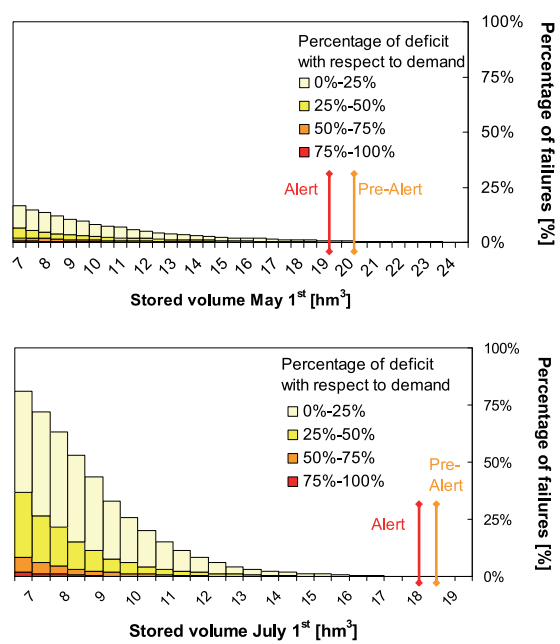
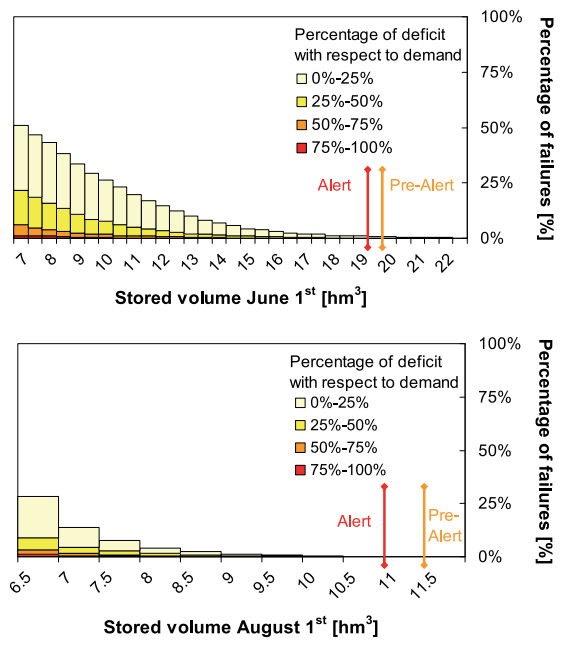

Fig. 12. Monthly risk of having failures and deficit percentage with respect to demand (from May to August). 


\section{Drought indices}

Drought indices are tools necessary at all levels of the planning process: as it was shown in the previous sections, in the Strategic Plan they are used to identify the zones most exposed to drought risk in the analyzed areas, whereas in the Management Plan and in the Contingency Plan they are used to define trigger values for the activation of the measures for impact prevention or mitigation.

Most of the proposed methodologies for the characterization and the monitoring of drought phenomena are based on drought indices with the capability of synthetically summarizing drought conditions in a specific moment for a particular area. Nevertheless, drought is difficult to represent through a single index, hence frequently more indices or aggregate indices are used.

In rainfed agriculture meteorological indices are particularly suitable, because they give the opportunity of establishing a direct spatial correlation between the drought event and the agricultural production, allowing drought risk maps to be drawn.

Many authors provide lists describing the characteristics of the main drought indices (e.g. Ntale \& Gan, 2003; Tsakiris et al., 2007a). Among them, the most widely used are the Palmer Drought Severity Index (PDSI; Palmer, 1965), the most "classical" drought index formulated to evaluate prolonged periods of both abnormally wet and abnormally dry weather conditions, and the Standardized Precipitation Index (SPI; McKee et al., 1993), a meteorological drought index based on the precipitation amount in a period of $\mathrm{n}$ months. Since SPI just needs precipitation data to be calculated, it has found widespread application. Guttman (1998) shows that the PDSI has a complex structure with an exceptionally long memory, while the SPI is an easily interpreted, simple moving average process. Hayes et al. (1999) describe the three main advantages in using SPI: the first and primary is its simplicity, the second is its variable time scale, and the third is its standardization. Nevertheless, the SPI is a meteorological index unable to take into account the effects of aquifers, soil, land use characteristics, crop growth and temperature anomalies, which influence agricultural and hydrological droughts.

Besides SPI, in the process of drought identification the MEDROPLAN Guidelines (Tsakiris et al., 2007a) suggest using also: the Reconnaissance Drought Index (RDI, Tsakiris et al., 2007b), also accounting for temperature anomalies (therefore for an eventual excessive evapotranspiration); deciles (Gibbs \& Maher, 1967), used by the Australian Drought Watch System, which compare monthly observed precipitation values with the quantiles corresponding to the not exceeded frequencies of $10 \%, 20 \%, \ldots 100 \%$ achieved from a long enough monthly precipitation series; the Surface Water Supply Index (SWSI, Shafer \& Dezman, 1982), aggregating information about precipitation, runoff, volumes stored in the reservoirs and snowpack, and expressing drought conditions in a standardized way. Furthermore, owing to their diffusion, other two indices are recalled: the run method (Yevjevich, 1967), based on the comparison between the time series of the analyzed hydrological index and a representative threshold of "normal" conditions, and the Palmer Hydrological Drought Index (Karl, 1986), a modified version of the PDSI for real-time monitoring.

An interesting way to account for soil and land use effects (in some respects, the way followed by Palmer to calculate PDSI) is to derive the drought indices starting from hydrological modeling. These indices can be called "comprehensive" drought indices, because they allow a more comprehensive picture of the water cycle and its elements 
(Niemeyer, 2008). A typical example of comprehensive drought index is the Groundwater Resource Index (GRI) derived by Mendicino et al. (2008a) using the monthly water balance model shown in figure 1 . For each single element where the model was applied $(5 \mathrm{~km}$ regular cell), the monthly values of groundwater detention (i.e. the storage $D$ ) were standardized (for almost all the cells and months the skewness test of normality showed that the series were normally distributed) through the following equation:

$$
G R I_{y, m}=\frac{D_{y, m}-\mu_{y, m}}{\sigma_{y, m}}
$$

where $G R I_{y, m}$ and $D_{y, m}$ are respectively the values of the index and of the groundwater detention for the year $y$ and the month $m$, while $\mu_{D, m}$ and $\sigma_{D, m}$ are respectively the mean and the standard deviation of groundwater detention values $D$ simulated for the month $m$ in a defined number of years (at least 30). This simple index, but based on several pieces of information provided by the water balance model, allows assessment of the deviation from the mean values of the available groundwater in a spatially-distributed way for the whole territory where the model is applied. Figure 13 shows the maps of the GRI distribution in northern Calabria for the months of April from 1979 to 2006. Examining the maps immediately the years with lower GRI values (the driest years, with brighter colors) are recognizable, as are the wettest years (darkest colors).

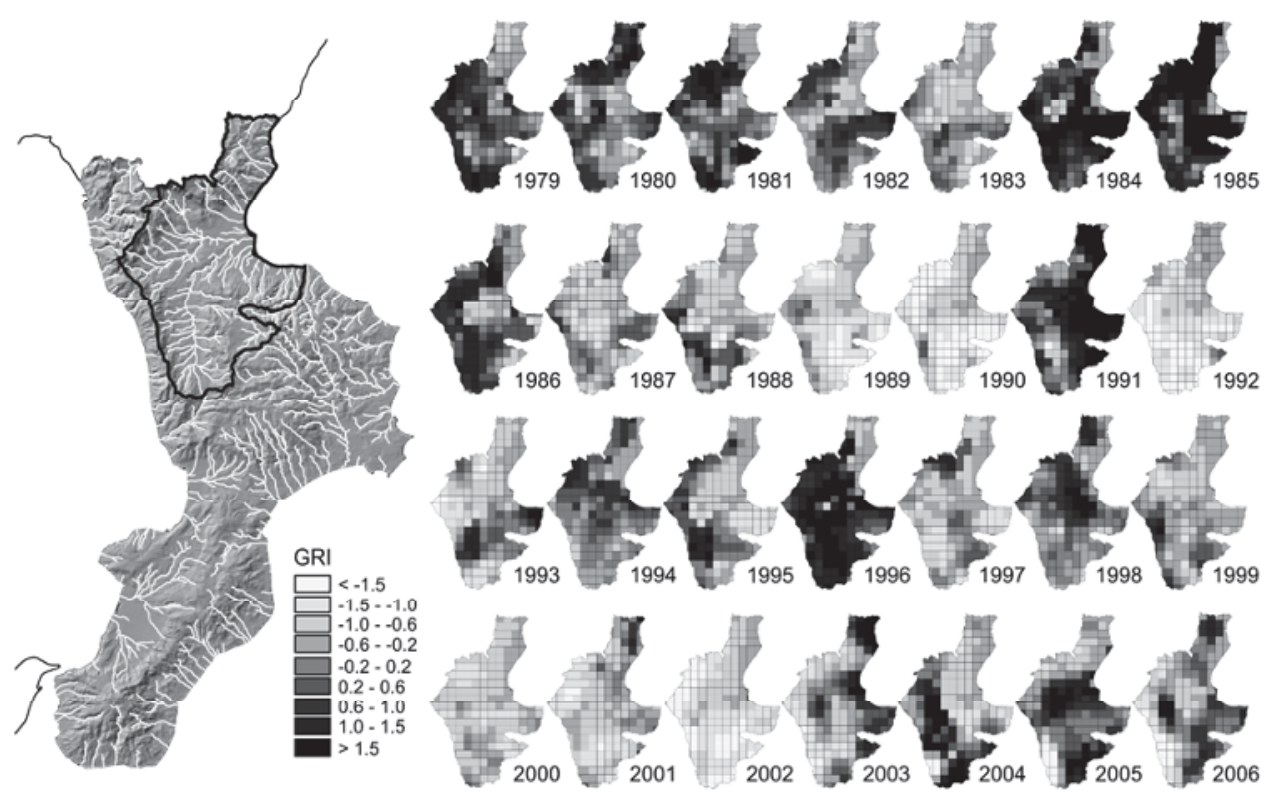

Fig. 13. Boundaries of the selected study area in Calabria and GRI distribution in northeastern Calabria for the months of April from 1979 to 2006 (from Mendicino et al., 2008a).

Other comprehensive indices were developed by Narasimhan \& Srinivasan (2005), who using the Soil and Water Assessment Tool (SWAT) model, derived two drought indices 
for agricultural drought monitoring, the Soil Moisture Deficit Index (SMDI) and the Evapotranspiration Deficit Index (ETDI), based respectively on weekly soil moisture and evapotranspiration (ET) deficit. Also Matera et al. (2007) derived a new agricultural drought index, called DTx, based on the daily transpiration deficit calculated by a water balance model.

In the few last years the possibility of using long data series coming from remote sensing has opened new and promising perspectives to satellite-derived drought indices, which have the advantage of being intrinsically spatially distributed. Anderson et al. (2007) provide a brief presentation of TIR-based drought indices, while a list of many NOAAAVHRR images-derived drought indices is presented by Bayarjargal et al. (2006). Zhang et al. (2005) exploit the capabilities of the MODerate resolution Imaging Spectroradiometer (MODIS) for monitoring and forecasting crop production using a satellite-based ClimateVariability Impact Index.

Several remote sensing-derived drought indices depend on the ratio ET/PET, where ET is actual evapotranspiration and PET potential evapotranspiration (e.g. Crop Water Stress Index (CWSI), Jackson et al., 1981; Drought Severity Index (DSI), Su et al., 2003; Evaporative Drought Index (EDI), Anderson et al., 2007; Yao et al., 2010). While PET is generally calculated by means of ground based measurements, ET is easily estimated through "residual" methods (e.g. SEBAL, Bastiaanssen et al., 1998; and Bastiaanssen, 2000; SEBI, Menenti \& Choudhury, 1993; S-SEBI, Roerink et al., 2000; SEBS, Su, 2002; TSEB, Norman et al., 1995; DisAlexi, Anderson et al., 1997; METRIC, Allen et al., 2007), where the evapotranspirative term is the residual term of the energy balance equation:

$$
\lambda E=R_{n}-G-H
$$

with $R_{n}$ net radiation, $G$ soil heat flux, $H$ sensible heat flux and $\lambda E$ latent heat flux, from which $E T$ is derived.

Even though at this stage very seldom they are used as operational tools, remote sensingderived indices are potentially very useful because they intrinsically provide space-time variation of drought phenomena, and the ratio ET/PET can be reasonably related to soil water content. For instance, the relative evaporation $\Lambda_{r}$ can be directly linked to the soil degree of saturation $\theta / \theta_{s}$ (Su et al., 2003). As an example, figure 14 shows the space-time evolution of the DSI, derived from SEBS and MODIS images, during summer 2006 in Northern Calabria. DSI is equal to $1-\lambda E / \lambda E_{\text {wet }}$ (where $\lambda E_{\text {wet }}$ is the latent heat flux estimated for the so-called "wet" pixel), hence higher DSI values indicate low actual evapotranspiration. A graph shown at the top of the figure provides information about precipitation in a micrometeorological station placed almost in the middle of the area (these data are only roughly representative, owing to the extension of the whole area). Figure 14 shows that the maps with the highest DSI values (e.g. July 20, but also September 4 and October 31), indicating drought stress conditions, are related to some of the most distant days from antecedent significant precipitation events.

To complete this brief review, a much-discussed issue is mentioned, i.e. the possibility of using the drought indices (especially SPI) to forecast stochastically the possible evolution of an ongoing drought (Cancelliere et al., 1996; Lohani et al., 1998; Bordi et al., 2005; Cancelliere et al., 2007). Several studies are also aimed at explaining and predicting possible drought conditions through the analysis of sea surface temperature (SST) and atmospheric circulation patterns (e.g. Wilby et al., 2004; Kim et al., 2006; Cook et al., 2007). 


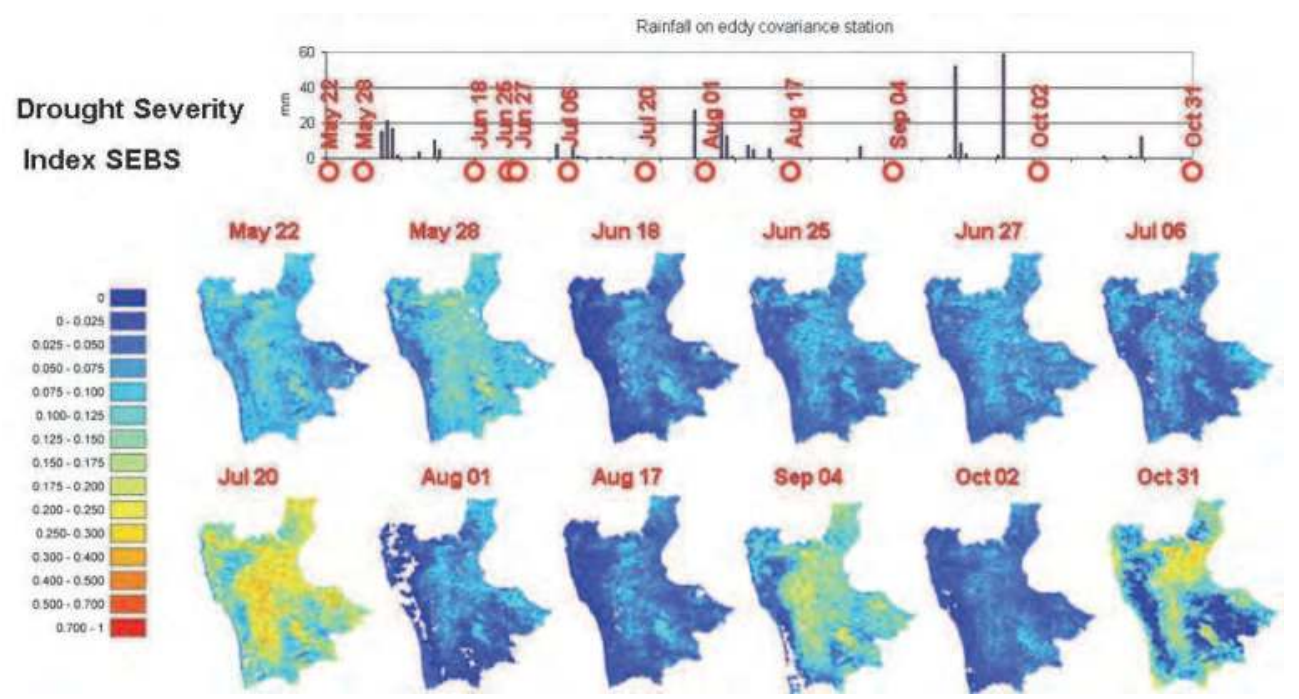

Fig. 14. Evolution of the DSI derived from SEBS in northern Calabria, from May 22 to October 31 2006. Top graph shows precipitation events on the representative micrometeorological station, placed approximately in the middle of the analyzed area.

However, when dealing with complex systems, where irrigated agriculture assumes a greater importance, one single index is often not able to capture the different features of drought and to take in account the effects of human activities (use of irrigation, water from reservoirs, wells, etc.) on the hydrological cycle. On the other hand, it is more practical to declare drought condition considering only one indicator. Thus, there is a growing interest in aggregating more indices. Keyantash \& Dracup (2004) use an Aggregate Drought Index that considers all relevant variables of the hydrological cycle through Principal Component Analysis (but they do not include groundwater in the suite of variables); instead Steinemann \& Cavalcanti (2006) use the probabilities of different indicators of drought and shortage, selecting the trigger levels on the basis of the most severe level of the indicator or the level of the majority of the indicators.

\section{Future scenarios}

The most critical scenarios discussed in the previous paragraphs could become "normal" circumstances if global climate change increases the prolonged and intense drought periods. At the end of the proposed analysis, it is useful to hypothesize some future climatic scenarios, with the aim of steering decision makers towards suitable water management policies, as it is suggested by the European Commission (COM, 2009).

The methodology usually followed to assess the hydrological consequences of climate change basically consists of a three-step process (Xu et al., 2005): (1) the development and use of general circulation models (GCMs) to provide future global climate scenarios under the effect of increasing greenhouse gases, (2) the development and use of downscaling techniques (both statistical methods and nested regional climate models, RCMs, which are being continuously improved) for "downscaling" the GCM output to the scales compatible 
with hydrological models, and (3) the development and use of hydrological models to simulate the effects of climate change on hydrological regimes at various scales. However, uncertainties within this framework have to be taken into account such as the internal variability of the climate system, model structure and parameterizations at different spatial and temporal scales, the downscaling techniques and bias correction methods and the choice of future climate scenarios. Several different approaches were chosen for providing operational solutions to these drawbacks ( $\mathrm{Xu}$ et al., 2005). However, numerous GCM simulations show almost univocal trends for global climate evolution. Giorgi \& Lionello (2008) highlight a robust and consistent description specifically for the Mediterranean area, with a significant reduction in precipitation, mainly in summertime. In the same area, according to Giorgi (2006), a major increase in climatic variability is also expected.

Below, some results obtained by Senatore et al. (2011) are shown related to future water availability in the main basin of northern Calabria (Crati River Basin, $1332 \mathrm{~km}^{2}$, Fig. 15) at the end of the XXI century. Future scenarios were made by applying the outputs of three Regional Climate Models (RCMs) RegCM, HIRHAM and COSMO-CLM to the newly developed Intermediate Space Time Resolution Hydrological Model (In-STRHyM). The analysis was performed using two time slices (1961-1990 and 2070-2099) with the SRES A2 (GCM HAD3AM) and A1B (GCM ECHAM5/MPI-OM) scenarios. Observed biases in simulated precipitation and temperature fields during the control period (1961-1990) were corrected before using meteorological outputs from each RCM as input for In-STRHyM.

In-STRHyM is a fully distributed hydrological model detailed enough to describe the hydrological processes of several small-medium sized Mediterranean basins. It has a relatively simple structure and is suitable for long period simulations to be undertaken within acceptable time frames. Specifically, In-STRHyM calculates separately transpiration and evaporation, depending on a remote sensing-derived vegetation fraction. Both transpiration and bare soil evaporation are estimated through the crop coefficient approach suggested by Allen et al. (1998), considering a water stress coefficient of the canopy depending on soil moisture conditions, and the reference values calculated through the Priestley \& Taylor (1972) equation.

The RCMs predict an increase in mean annual temperature from $3.5{ }^{\circ} \mathrm{C}$ to $3.9{ }^{\circ} \mathrm{C}$, and a decrease in mean annual precipitation from $9 \%$ to $21 \%$. The effects of the changes in the forcing meteorological variables are relevant for all the hydrological output variables. Here we highlight results achieved for actual evapotranspiration (ET). This variable tends to decrease with reduced precipitation, but it increases with higher temperatures. Lower decrease in precipitation predicted by HIRHAM, together with the higher temperatures, leads to an average year ET increase of $+2.5 \%$, while for RegCM and CLM the annual mean reduction is equal to $-5.1 \%$ (Fig. 15) and $-8.3 \%$, respectively. However, in the summer period, that is the irrigation period, in all cases an ET reduction is achieved (from $-1.0 \%$ with HIRHAM to $-9.1 \%$ with RegCM, Fig. 15), indicating a decrease in water availability for plants and soil. This water stress is better highlighted when considering simulated root zone soil moisture. For this variable a reduction is predicted, differently from $E T$, during the whole year $(-20.7 \% \pm 1.9 \%,-12.8 \% \pm 1.9 \%$ and $-17.6 \% \pm 1.8 \%$ with RegCM, HIRHAM and CLM, respectively). Figure 16 shows as an example the daily changes computed using RegCM (the behavior considering the other RCMs is similar): they are less relevant in winter and spring, but the reduction is dramatic in summer and early autumn, due to the increased evaporative demand (up to $-40 \%$ with $\operatorname{RegCM}$ ). 

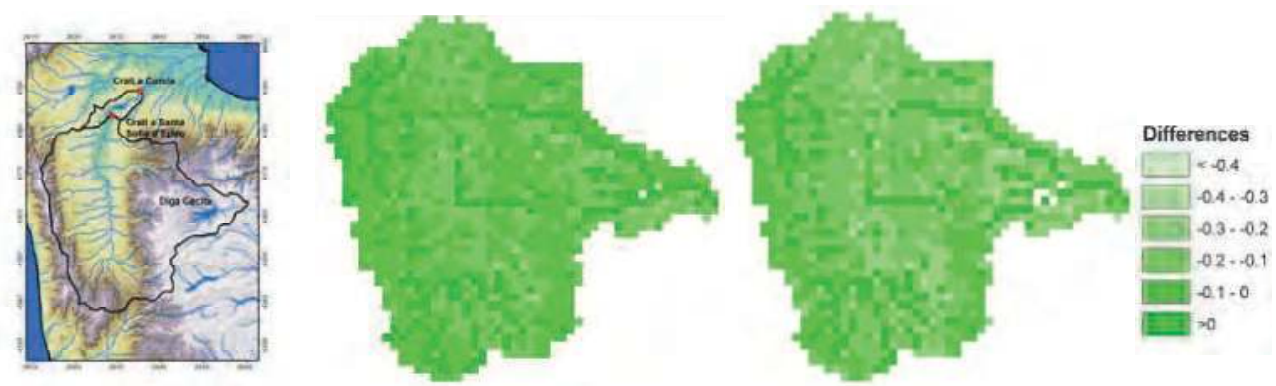

Fig. 15. Location of the Crati River Basin (left) and spatially distributed percentage changes in annual actual evapotranspiration (middle) and in actual evapotranspiration during the April-September irrigation period (right) simulated using RegCM (2070-2099 vs 1961-1990) (adapted from Senatore et al., 2011).

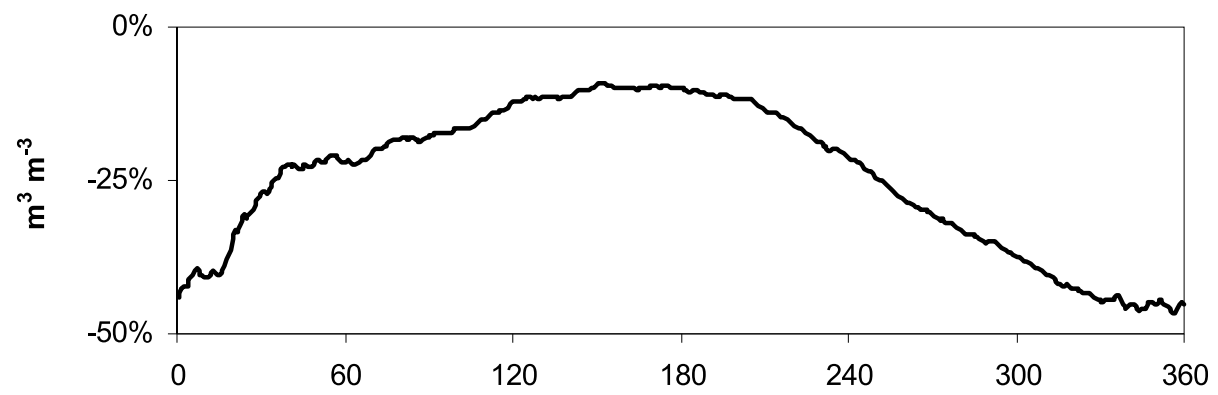

Fig. 16. Daily changes in root zone soil moisture computed using RegCM. RCM values are rescaled over 360 days, with the first day being October the $1^{\text {st }}$ (readapted from Senatore et al., 2011).

\section{Summary and conclusions}

Evapotranspiration deeply affects the water resources availability in Calabria (average annual actual evapotranspiration estimated equal to almost $60 \%$ of the average cumulated annual rainfall). Highest water requirements come from agriculture, where losses due to evapotranspiration demand have to be re-equilibrated by huge amounts of water, mainly in the summer hot and dry period. The analysis of the comparison between the available water resource and the water demand was carried out considering both the "normal" conditions due to meteorological forcing, and the most critical derived by intense and prolonged drought periods. In the first case, neglecting the very conservative constraints proposed by the Regional Basin Authority for the minimum flow requirements, specific issues are not observed, the residual water availability being sufficient. Several problems arise instead when drought conditions occur: in these cases the development of guidelines is essential to define operative aspects about the individuation of the water use priorities, to characterize different drought levels, to individuate the main objectives of water management related to these levels, and to determine and apply the mitigation measures. 
The proposed example of water resource management under shortage conditions in the agricultural area of the Sibari Plain shows the benefits that a proactive approach may provide with respect to the classical approaches based on emergency measures, which are usually expensive and not efficient. Within a proactive approach, specific care should be taken into account for reducing evapotranspiration losses through appropriate agronomic techniques. This action has to be considered as a strategic measure, with an impact on water scarcity reduction comparable to the effect of structural measures.

The review of drought indices showed that evapotranspiration could provide useful insights: i) when adopted within comprehensive indices, considering the effects of the whole water balance, and not only of some components, on water resources availability; ii) and mainly, when dealing with optical remote sensing techniques, because these allow to estimate in a relatively easy way the spatially distributed actual evapotranspiration over a specific area, and then they can relate this quantity to soil moisture and to the incoming of drought events.

Finally, applying some future scenarios with different GCMs and RCMs, it was observed that in Calabria the issues related to water resource management under shortage conditions in the next few years will be more frequent and intense, affecting wider areas. Evapotranspiration will be "tied down" by reduced precipitation (reducing its magnitude) and by higher temperatures (providing an opposite effect). It will not clearly increase or decrease on an annual basis, but in any case it will contribute to reduce useable water from the soil, needed for agricultural purposes. The hypothesized scenarios of climate change, though subject to uncertainty, have to be intended as an important part of knowledge for the planning of future interventions on the water resource by the Public Authorities, and for defining the optimal criteria to evaluate the amount of public investments.

\section{References}

Allen, R., Pereira, L.S., Raes, D. \& Smith, M. (1998). Crop Evapotranspiration - Guidelines for Computing Crop Water Requirements. FAO Irrigation and Drainage Paper 56, FAO, Rome.

Allen, R.G., Tasumi, M. \& Trezza, R. (2007). Satellite-based Energy Balance for MApping Evapotranspiration with Internalized Calibration (METRIC) - Model. J. Irrig. and Drain. Engrg, ASCE 133(4), 380-394.

Anderson, M., Norman, J., Diak, G., Kustas, W. \& Mecikalski, J. (1997). A two-source timeintegrated model for estimating surface fluxes from thermal infrared satellite observations. Remote Sensing of Environment 60: 195-216.

Anderson, M.C., Norman, J.M., Mecikalski, J.R., Otkin, J.A. \& Kustas, W.P. (2007). A climatological study of evapotranspiration and moisture stress across the continental United States based on thermal remote sensing: 2. Surface moisture climatology. J. Geophysical Research; 112: art. No. D11112.

Bastiaanssen, W.G.M., Menenti, M., Feddes, R.A. \& Holtslag, A.A.M. (1998) A remote sensing surface energy balance algorithm for land (SEBAL). 1. Formulation. Journal of Hydrology 212-213: 198-212.

Bastiaanssen, W.G.M. (2000). SEBAL-based sensible and latent heat fluxes in the irrigated Gediz Basin, Turkey. Journal of Hydrology 229: 87-100. 
Bayarjargal, Y., Karnieli, A., Bayasgalan, M., Khudulmur, S., Gandush, C. \& Tucker, C.J. (2006). A comparative study of NOAA-AVHRR derived drought indices using change vector analysis. Remote Sensing of Environment; 105: 9-22.

Bordi, I., Fraedrich, K., Petitta, M. \& Sutera, A. (2005). Methods for predicting drought occurrences. Proc. of the 6th EWRA International Conference, Menton, France, 7-10 September 2005.

Cancelliere, A., Rossi, G. \& Ancarani, A. (1996). Use of Palmer Index as drought indicator in Mediterranean regions. Proc. IAHR Congress "From flood to drought", Sun City, South Africa, August 5-7, 1996, pp. S4.12. 1-25.

Cancelliere, A., Di Mauro, G., Bonaccorso, B. \& Rossi, G. (2007). Stochastic forecasting of drought indices. In: Rossi, G., Vega, T., Bonaccorso, B. (Eds.), Methods and tools for drought analysis and management, Water Science and Technology Library, vol. 62, Springer, Dordrecht, 83-100.

COM - Commission of the European Communities, (2007). Addressing the challenge of water scarcity and droughts in the European Union, Communication from the Commission to the European Parliament and the Council, 414, 18.7.2007, Brussels, $14 \mathrm{pp}$.

COM - Commission of the European Communities, (2009). Towards a comprehensive climate change agreement in Copenhagen, Communication from the Commission to the European Parliament, the Council, the European Economic and Social Committee and the Committee of the Regions, 39, 28.1.2009, Brussels, 14 pp.

Cook, E.R., Seager, R., Cane, M.A. \& Stahle, D.W. (2007). North American drought: Reconstructions, causes, and consequences. Earth-Science Review; 81: 93-134.

Cowie, G., Davis, M., Holmbeck-Pelham, S., Freeman, B., Freeman, M., Hatcher, K., Jackson, R., Miller Keyes, A., Merrill, M., Meyer, J., Sutherland, E. \& Wenger, S. (2002). Reservoirs in Georgia: Meeting Water Supply Needs While Minimizing Impacts, University of Georgia's River Basin Science and Policy Center, Athens, Georgia,

Dworak, T., Berglund, M., Laaser, C., Strosser, Roussard, P. J., Grandmougin, B., Kossida, M., Kyriazopoulou, I., Berbel, J., Kolberg, S., Rodrigues-Diaz, J.A. \& Montesinos, P. (2007). EU water saving potential, Ecologic-Institute for International and European Environmental Policy, ENV.D.2/ETU/2007/0001r.

Georgia Department of Natural Resources: Georgia Drought Management Plan, Atlanta, GA, (2003).

Gibbs, W.J. \& Maher, J.V. (1967). Rainfall deciles as drought indicators. Bureau of Meteorology Bulletin No. 48, Commonwealth of Australia, Melbourne.

Giorgi, F. (2006). Climate change hot-spots. Geophys. Res. Lett. 33 L08707.

Giorgi, F. \& Lionello, P. (2008). Climate change projections for the Mediterranean region. Glob. Planet. Change 63 90-104.

Guttman, N.B. (1998). Comparing the Palmer Drought Index and the standardized precipitation index. J. Am.Water Res. Assoc.; 34 (1): 113-121.

Hayes, M.J., Svoboda, M.D., Wilhite, D.A. \& Vanyarkho, O.V. (1999). Monitoring the 1996 drought using the standardized precipitation index. Bulletin of the American Meteorological Society; 80: 429-438. 
IPCC (2007). Climate Change 2007. The Physical Science Basis. Contribution of Working Group I to the Fourth Assessment Report of the Intergovernmental Panel on Climate Change [Solomon, S., D. Qin, M. Manning, Z. Chen, M. Marquis, K.B. Averyt, M. Tignor and H.L. Miller (eds.)]. Cambridge University Press, Cambridge, United Kingdom and New York, NY, USA, 996 pp., 2007.

Jackson, R.D., Idso, S.B., Reginato, R.J. \& Printer, P.J. (1981). Canopy temperature as a crop water stress indicator. Water Res. 17, 1133-1138.

Karl, T.R. (1986). The Sensitivity of the Palmer Drought Severity Index (PDSI) and Palmer's Z-index to their calibration coefficients including potential evapotranspiration. Journal of Climate and Applied Meteorology; 25: 77-86.

Keyantash, J.A. \& Dracup, J.A. (2004). An aggregate drought index: Assessing drought severity based on fluctuations in the hydrologic cycle and surface water storage. Water Resources Research; 40(9): Art. No. W09304.

Kim, T.W., Valdés, J.B., Nijssen, B. \& Roncayolo, D. (2006). Quantification of linkages between large-scale climatic patterns and precipitation in the Colorado River Basin. J. Hydrology; 321: 173-186.

Kunstmann, H., Schneider, K., Forkel, R. \& Knoche, R. (2004). Impact analysis of climate change for an alpine catchment using high resolution dynamic downscaling of ECHAM4 time slices, Hydrology and Earth System Sciences, Vol. 8, 1031-1045.

Lohani, V.K., Loganathan, G.V. \& Mostaghimi, S. (1998). Long-term analysis and short-term forecasting of dry spells by Palmer Drought Severity Index. Nord. Hydrol.; 29(1): 2140.

Matera, A., Fontana, G., Marletto, V., Zinoni, F., Botarelli, L. \& Tomei, F. (2007). Use of a new agricultural drought index within a regional drought observatory. In: Rossi, G., Vega, T., Bonaccorso, B. (Eds.), Methods and tools for drought analysis and management, Water Science and Technology Library, vol. 62, Springer, Dordrecht, 103124.

McKee, T.B., Doesken, N.J. \& Kleist, J. (1993). The relationship of drought frequency and duration to time scales, Proceedings of the 8th Conference on Applied Climatology, American Meteorological Society, Anaheim, CA, Boston, MA, pp. 179-184.

Mendicino, G., Senatore, A. \& Versace, P. (2005). I deflussi minimi annuali, stagionali e di magra nei corsi d'acqua calabresi, Acts of the 25th Corso di Aggiornamento in Tecniche per la Difesa dall'Inquinamento, ed. G. Frega, BIOS, Cosenza, pp. 89-117.

Mendicino, G. \& Versace, P. (2007). Integrated Drought Watch System: A Case Study in Southern Italy, Water Resour. Manage., Vol. 21, 1409-1428.

Mendicino, G., Senatore, A. \& Versace, P. (2008a). A Groundwater Resource Index (GRI) for drought monitoring and forecasting in a Mediterranean climate, J. Hydrol., Vol. 357(3-4), pp. 282-302.

Mendicino, G., Senatore, A. \& Versace, P. (2008b). “Water resources management in agriculture under drought and water shortage conditions: a case study in southern Italy", European Water 23/24, pp. 41-56.

Menenti, M. \& Choudhury, B.J. (1993). Parameterization of land surface evapotranspiration using a location dependent potential evapotranspiration and surface temperature 
range. In: Bolle H.J. et al. (Eds.), Exchange Processes at the Land Surface for a Range of Space and Time Scales, IAHS Publication 212, 561-568.

Moore, I.D., Norton, T.W \& Williams, J.E. (1993). Modelling environmental heterogeneity in forested landscapes, J. Hydrol., Vol. 150, 717-747.

Munda, G. (1995). Multicriteria Evaluation in a Fuzzy Environment, Series: Contributions to Economics, Physica-Verlag, Heidelberg.

Nakícenovíc, N., Alcamo, J., Davis, G., de Vries, B., Fenhann, J., Gaffin, S., Gregory, K., Grübler, A., Jung, T.Y., Kram, T., Emilio la Rovere, E., Michaelis, L., Mori, S., Morita, T., Pepper, W., Pitcher, H., Price, L., Riahi, K., Roehrl, A., Rogner, H.-H., Sankovski, A., Schlesinger, M.E., Shukla, P.R., Smith, S., Swart, R.J., van Rooyen, S., Victor, N. \& Dadi, Z. (2000). Special Report on Emissions Scenarios, Cambridge University Press, Cambridge, available on-line: http://www.grida.no/climate/ipcc/emission/.

Narasimhan, B. \& Srinivasan, R. (2005). Development and evaluation of Soil Moisture Deficit Index (SMDI) and Evapotranspiration Deficit Index (ETDI) for agricultural drought monitoring. Agric. For. Meteorol.; 133: 69-88.

Niemeyer, S. (2008). New drought indices. Options méditerranéennes, SERIE A: Séminaiers Méditerranéens, N. 80, “Drought Management: Scientific and Technological Innovations", pp. 267-274.

Norman, J., Kustas, W. \& Humes, K. (1995). A two-source approach for estimating soil and vegetation energy fluxes from observations of directional radiometric surface temperature. Agricultural and Forest Meteorology 77: 263-293.

Ntale, H.K. \& Gan, T.H. (2003). Drought indices and their application to East Africa. Int. J. Climatol.; 23: 1335-1357.

Palmer, W.C. (1965). Meteorological drought, Research Paper 45. U.S. Department of Commerce, Weather Bureau, Washington, DC.

Pereira ,L.S. (2007). Drought impacts in agriculture: water conservation and water saving practices and management, in: G. Rossi et al. (Eds.), Water Science and Technology Library, vol. 62: Methods and Tools for Drought Analysis and Management, Springer Netherlands, pp.349-373.

Priestley, C.H.B. \& Taylor, R.J. (1972). On the assessment of the surface heat flux and evaporation using large-scale parameters, Monthly Weather Review, Vol. 100, 81-92.

Qian, T., Dai, A., Trenberth, K.E. \& Oleson, K.W. (2006). Simulation of global land surface conditions from 1948-2004. Pt I: Forcing data and evaluations. J. Hydrometeorol., 7, 953-975.

Rivas-Martinez, S. (1995). Bases para una nueva clasificacion bioclimatica de la Tierra. Folia Botanica Matritensis 16.

Roerink, G.J., Su, B. \& Menenti, M. (2000). S-SEBI A simple remote sensing algorithm to estimate the surface energy balance. Physics and Chemistry of the Earth (B) 25(2): 147157.

Rossi, G. (2003). An integrated approach to drought mitigation in Mediterranean regions, in: G. Rossi et al. (Eds.), Tools for drought mitigation in Mediterranean regions, Kluwer Academic Publishing, Dordrecht, pp. 3-18. 
Rossi, G., Castiglione, L. \& Bonaccorso, B. (2007). Guidelines for planning and implementing drought mitigation measures, in: G. Rossi et al. (Eds.), Water Science and Technology Library, Vol. 62: Methods and Tools for Drought Analysis and Management, Springer Netherlands, pp.325-347.

Senatore, A., Mendicino, G., Smiatek, G. \& Kunstmann, H. (2011). Regional climate change projections and hydrological impact analysis for a Mediterranean basin in southern Italy. Journal of Hydrology, 399(1-2), 70-92.

Shafer, B.A. \& Dezman, L.E. (1982). Development of a Surface Water Supply Index (SWSI) to assess the severity of drought conditions in snowpack runoff areas. Proceedings of the Western Snow Conference, Colorado State University, Fort Collins, Colorado, 164175.

Steinemann, A.C. \& Cavalcanti, L.F.N. (2006). Developing multiple indicators and triggers for drought plans. J. water resources planning and management, ASCE 132(3): 164-174.

$\mathrm{Su}, \mathrm{Z}$. (2002). The surface energy balance system (SEBS) for estimation of turbulent heat fluxes. Hydrology and Earth System Sciences 6(1): 85-99.

Su, Z., Yacob, A., Wen, J., Roerink, G., He, Y., Gao, B., Boogaard, H. \& van Diepen, C. (2003). Assessing relative soil moisture with remote sensing data: Theory, experimental validation, and application to drought monitoring over the North China Plain. Physics and Chemistry of the Earth (B) 28(1-3): 89-101.

Thornthwaite, C.W. \& Mather, J.R. (1955). The water balance, Climatology, Drexel Inst. Of Technology, Centeron, New Jersey.

Tsakiris, G., Loukas, A., Pangalou, D., Vangelis, H., Tigkas, D., Rossi, G. \& Cancelliere, A. (2007a). Drought characterization, in: Drought Management Guidelines Technical Annex, Options méditerranéennes, Série B: Etudes et Recherches, Numéro 58.

Tsakiris, G., Pangalou, D. \& Vangelis, H. (2007b). Regional drought assessment based on the Reconnaissance Drought Index (RDI). Water Resources Management; 21(5): 821-833.

Water Scarcity Drafting Group (2006). Water scarcity management in the context of WFD, Salzburg, June 1-2.

Wilby, R.L., Wedgbrow, C.S. \& Fox, H.R. (2004). Seasonal predictability of the summer hydrometeorology of the River Thames, UK. J. Hydrology; 295: 1-16.

WHO/Unicef (2006). Protecting and Promoting Human Health, in: The 2nd UN World Water Development Report: "Water, a shared responsibility", available on line: http://www.unesco.org/water/wwap/wwdr/wwdr2/.

Xu, C., Widén, E. \& Halldin, S. (2005). Modelling Hydrological Consequences of Climate Change-Progress and Challenges. Advances in Atmospheric Sciences, vol.22, no.6, 789797.

Yao, Y., Liang, S., Qin, Q. \& Wang, K., (2010). Monitoring Drought over the Conterminous United States Using MODIS and NCEP Reanalysis-2 Data. Journal of Applied Meteorology and Climatology, 49, 1665-1680.

Yevjevich, V. (1967). An objective approach to definitions and investigations of continental hydrologic droughts. Hydrology Papers, Colorado State University, Fort Collins, pp. 23.

Yevjevich, V., Hall, W.A. \& Salas, J.D. (1978). Drought research needs, Water Resources Publications, Fort Collins, Colorado. 
Yevjevich, V., Da Cunha, L. \& Vlachos, E. (1983). Coping with droughts, Water Resources Publications, Littleton, Colorado.

Zhang, P., Anderson, B., Tan, B., Huang, D. \& Myneni, R. (2005). Potential monitoring of crop production using a satellite-based Climate-Variability Impact Index. Agric. For. Meteorol.; 132: 344-358. 


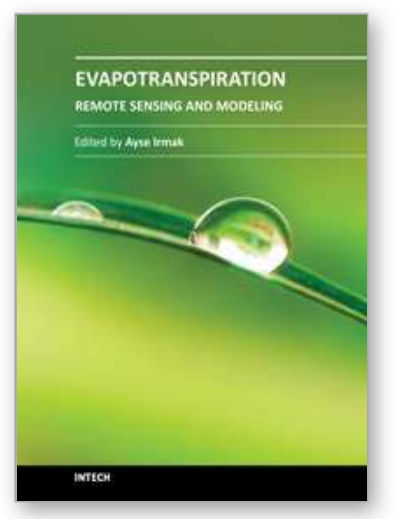

\section{Evapotranspiration - Remote Sensing and Modeling}

Edited by Dr. Ayse Irmak

ISBN 978-953-307-808-3

Hard cover, 514 pages

Publisher InTech

Published online 18, January, 2012

Published in print edition January, 2012

This edition of Evapotranspiration - Remote Sensing and Modeling contains 23 chapters related to the modeling and simulation of evapotranspiration (ET) and remote sensing-based energy balance determination of ET. These areas are at the forefront of technologies that quantify the highly spatial ET from the Earth's surface. The topics describe mechanics of ET simulation from partially vegetated surfaces and stomatal conductance behavior of natural and agricultural ecosystems. Estimation methods that use weather based methods, soil water balance, the Complementary Relationship, the Hargreaves and other temperatureradiation based methods, and Fuzzy-Probabilistic calculations are described. A critical review describes methods used in hydrological models. Applications describe ET patterns in alpine catchments, under water shortage, for irrigated systems, under climate change, and for grasslands and pastures. Remote sensing based approaches include Landsat and MODIS satellite-based energy balance, and the common process models SEBAL, METRIC and S-SEBS. Recommended guidelines for applying operational satellite-based energy balance models and for overcoming common challenges are made.

\section{How to reference}

In order to correctly reference this scholarly work, feel free to copy and paste the following:

Giuseppe Mendicino and Alfonso Senatore (2012). The Role of Evapotranspiration in the Framework of Water Resource Management and Planning Under Shortage Conditions, Evapotranspiration - Remote Sensing and Modeling, Dr. Ayse Irmak (Ed.), ISBN: 978-953-307-808-3, InTech, Available from:

http://www.intechopen.com/books/evapotranspiration-remote-sensing-and-modeling/the-role-ofevapotranspiration-in-the-framework-of-water-resource-management-and-planning-under-shor

\section{INTECH}

open science | open minds

\section{InTech Europe}

University Campus STeP Ri

Slavka Krautzeka 83/A

51000 Rijeka, Croatia

Phone: +385 (51) 770447

Fax: +385 (51) 686166

www.intechopen.com

\section{InTech China}

Unit 405, Office Block, Hotel Equatorial Shanghai

No.65, Yan An Road (West), Shanghai, 200040, China 中国上海市延安西路65号上海国际贵都大饭店办公楼 405 单元

Phone: +86-21-62489820

Fax: $+86-21-62489821$ 
(C) 2012 The Author(s). Licensee IntechOpen. This is an open access article distributed under the terms of the Creative Commons Attribution 3.0 License, which permits unrestricted use, distribution, and reproduction in any medium, provided the original work is properly cited. 